\title{
Regulatory T Cell and Forkhead Box Protein 3 as Modulators of Immune Homeostasis
}

\section{Leonn Mendes Soares Pereira ${ }^{1,2}$, Samara Tatielle Monteiro Gomes ${ }^{1,2}$, Ricardo Ishak $^{1}$ and Antonio Carlos Rosário Vallinoto ${ }^{\text {* }}$}

${ }^{1}$ Laboratório de Virologia, Instituto de Ciências Biológicas, Universidade Federal do Pará, Belém, Pará, Brazil, ${ }^{2}$ Programa de Pós-Graduação em Biologia de Agentes Infecciosos e Parasitários, Instituto de Ciências Biológicas, Universidade Federal do Pará, Belém, Pará, Brazil

The transcription factor forkhead box protein 3 (FOXP3) is an essential molecular marker of regulatory $\mathrm{T}$ cell (Treg) development in different microenvironments. Tregs are cells specialized in the suppression of inadequate immune responses and the maintenance of homeostatic tolerance. Studies have addressed and elucidated the role played by FOXP3 and Treg in countless autoimmune and infectious diseases as well as in more specific cases, such as cancer. Within this context, the present article reviews aspects of the immunoregulatory profile of FOXP3 and Treg in the management of immune homeostasis, including issues relating to pathology as well as immune tolerance.

Keywords: forkhead box protein 3, regulatory $\mathrm{T}$ cell lymphocytes, regulatory status, immunotolerance, immune homeostasis

\section{INTRODUCTION}

The establishment of an immune response occurs due to fortuitous stimuli generated by an unlimited set of extrinsic and intrinsic factors of the organism. In order to be launched, a highly interactive network must be instituted among the innate components of immunity, which will recognize molecular patterns associated with the pathological condition. The design of the response follows a complex recruitment of specialized cells (1-3) with the components of adaptive immunity, which specifically regulate effector cell response through the production of pleiotropic immunologic mediators $(4,5)$.

The success of the immune response is accompanied by the potential risk in developing damage and autoimmune reactions against the organism. The loss of the discrimination between the selfelements and the non-self-elements generates mechanisms for the breakdown of immunological tolerance that are harmful to the maintenance of homeostasis $(6,7)$. Therefore, the organism must have mechanisms to regulate the exacerbated expression of the immune response in order to reduce the harmful effects on the damaged system (8).

In this context, regulatory $\mathrm{T}$ cell (Treg) assumes a remarkably important role in regulating the immune response by performing a suppressor function through different mechanisms of action $(9$, 10). It is not by chance that alterations in the frequency and/or development of these cells are a risk factor for both the susceptibility to infectious agents and the worsening of the clinical condition of an already established pathology $(11,12)$. One of the best characterized markers of Treg is the forkhead box protein 3 (FOXP3) transcription factor, the production of which is closely related to the development and function of most Treg, both in the subpopulation that develops in the intrathymic environment and in those that are peripherally induced in secondary lymphoid organs $(13,14)$. 
Currently, complementary studies on the role of Treg and FOXP3 in a series of pathologies prevail in scientific research, mainly seeking to uncover the therapeutic potential that these factors can offer (15-17).

\section{FOXP3 STRUCTURE}

The transcription factor FOXP3, a 47-kDa protein composed of 431 amino acids (Figure 1), is a member of the subfamily $\mathrm{P}$ of the FOX protein family (18). These proteins share a preserved DNA binding domain known as forkhead/winged helix, which contains three $\alpha$ helices and two large loops that resemble the double wings of butterflies (19). More than 100 such proteins have been identified, and a proposal to standardize their nomenclature was developed, resulting in the term FOX (forkhead box); subclasses are indicated with letters and their members with Arabic numerals ("FOX," subfamily "P," and member "3"). For humans, the abbreviated name is fully written with uppercase letters (20).

In addition to the forkhead domain located in the C-terminal portion, FOXP3 also has a central domain, which encompasses the $\mathrm{C} 2 \mathrm{H} 2$ zinc finger $(\mathrm{ZnF})$ and leucine zipper (LeuZip) regions, and a repressor domain in the $\mathrm{N}$-terminal portion (Figure 1) $(21,22)$.
Interaction of the forkhead domain with the target sequence of activator protein-1 (AP-1) blocks the activity of the complex formed by AP- 1 and the nuclear factor of activated T cells (NFAT), which interferes with $\mathrm{T}$ cell activation (23). The ZnF and LeuZip domains are conserved among subfamily P members, being traditionally considered as protein interaction domains responsible for the formation of oligomers essential for the function of FOXP3 (24). In turn, the repressor domain is rich in proline and plays a crucial role in the repression of FOXP3 target genes through its interaction with chromatin remodeling factors (25).

The FOXP3 gene comprises 11 exons, measures $21 \mathrm{~kb}$ and is located on position Xp11.23 in the short arm of the X chromosome (Figure 1) (26). Differential expression of FOXP3 between species was demonstrated by Western blotting in a study that compared the human and mouse proteins. In humans, FOXP3 occurs in two closely spaced bands, the lower corresponding to the isoform without the second encoding exon (FOXP3 $\Delta$ exon2) and the upper representing the wild isoform, an ortholog of the mouse protein $(27,28)$. The wild isoform seems to interact with the RAR-related orphan receptor alpha, inhibiting its role as a transcriptional activator (29). In turn, variant isoforms significantly inhibit $\mathrm{CD} 4^{+} \mathrm{T}$ cell activation induced by the chimeric $\mathrm{CD} 28 / \mathrm{TCR} \zeta$ receptor $(30)$.

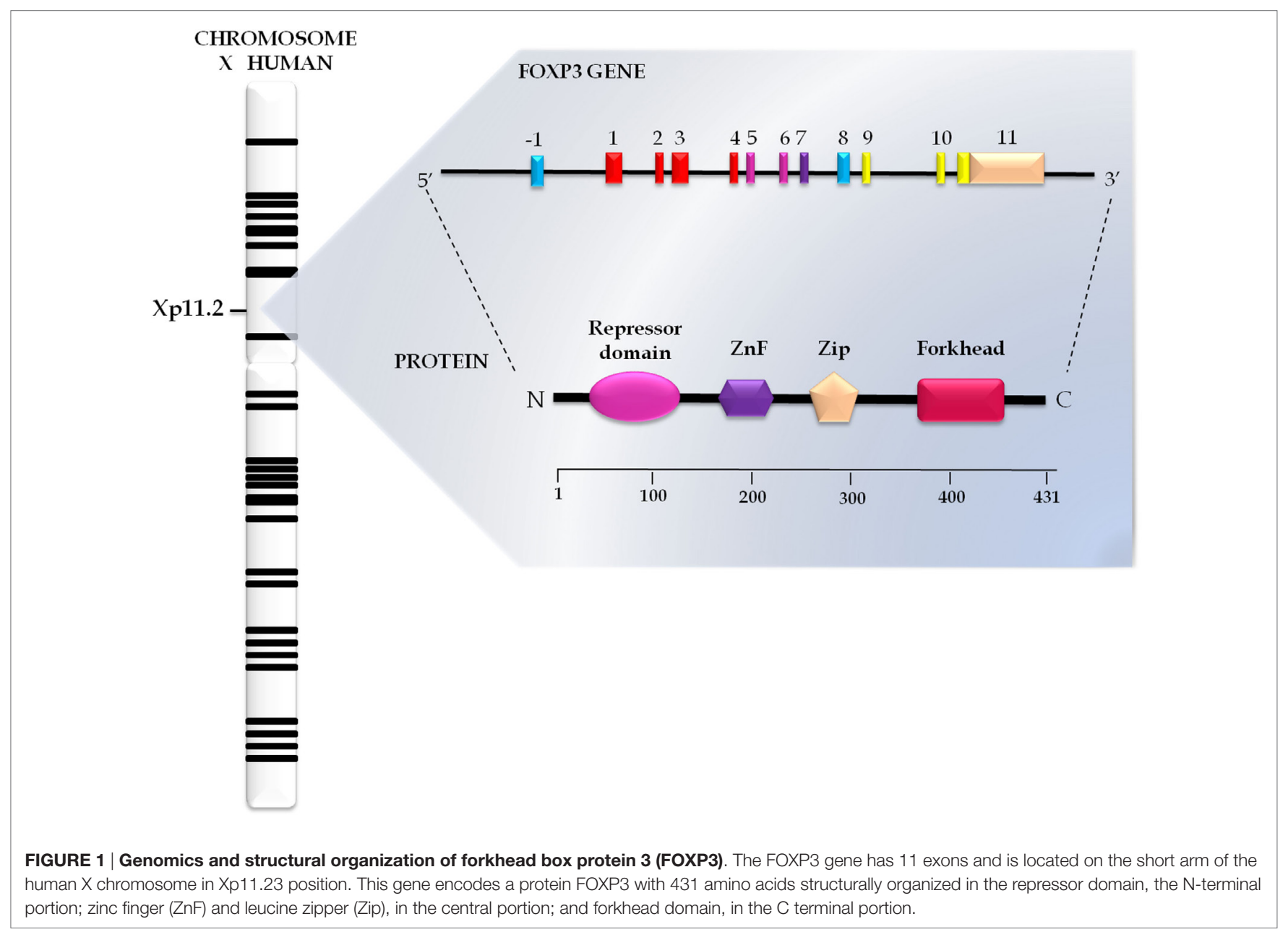




\section{FOXP3 FUNCTION AND REGULATION}

FOXP3 is an essential molecular marker of Treg development and function in the thymus and peripheral lymphoid organs (31). According to available data, the initial signal for the induction of FOXP3 expression is triggered by the presentation of peptides derived from host's autoantigens through $\mathrm{T}$ cell receptor-major histocompatibility complex (TCR-MHC) class II interactions (32, 33). The immunostimulation potential of antigens and the early inflammatory environment are determinants of Treg differentiation into new effector phenotypes (34).

Gain-of-function studies have demonstrated a relationship between FOXP3 and Treg. Retroviral FOXP3 transfer to $\mathrm{CD} 4{ }^{+} \mathrm{CD} 25^{-} \mathrm{T}$ cells converted them into a regulatory phenotype similar to the natural lineage; as a result, in addition to ectopic FOXP3 expression, these cells exhibited low interleukin (IL)-2, IL4, and interferon (IFN) $\gamma \gamma$ secretion after stimulation and upregulated the expression of typical Treg surface markers, such as CD25, cytotoxic T-lymphocyte-associated protein 4 (CTLA4 ), and CD103. These data emphasize the double role of FOXP3 as a transcriptional repressor and activator (31). In its role as a repressor, FOXP3 interacts with transcription factors NFAT (35) and nuclear factor kappa B (NF-kB) and blocks the expression of cytokine-encoding genes (36). However, whether FOXP3 regulates transcriptional activation in a direct or an indirect manner has not yet been elucidated (37).

From the molecular perspective, FOXP3 interacts with the Tip60 histone acetyltransferase and several members of class I and II histone deacetylases. Biochemical and spectrophotometric analyzes reveal that the transcriptional complex of FOXP3 may contain more than 300 associated proteins involved as transcriptional cofactors. This complex regulates chromatin remodeling through histone acetylation and deacetylation and facilitates the interaction of FOXP3 with its target genes $(38,39)$; it also plays an essential role in the determination of the central and peripheral responsiveness of $\mathrm{T}$ cells. The oligomerization status of FOXP3 plays a key role in binding to promoter sequences (40). Interaction between chromatin remodeling complexes may also occur to regulate specific transcription sites located in the same promoter region, thus modulating loci related to cell line identity (41).

Cytokine transforming growth factor (TGF) $-\beta$ is able to induce FOXP3 expression and confer functional suppressor activity to $\mathrm{T}$ cells initially from a non-regulatory lineage, even in the absence of costimulatory signals. TGF- $\beta$ also induces secretion of the cytokine IL-10, which is related to the generation of peripheral Treg (pTreg). All together, these data suggest that TGF- $\beta$ sustains regulatory networks through modulation of FOXP3 expression and development of ectopic Treg (14, 42, 43). Furthermore, IL-2 sustains the function and survival of Treg through the induction of FOXP3 mRNA expression and stabilization and the upregulation of pro-survival protein myeloid cell leukemia 1 expression, which counterregulates the pro-apoptotic protein Bim (44). By interacting with TGF- $\beta$, IL-2 increases the expression of Treg markers, such as CD25, CTLA-4, CD122, and glucocorticoidinduced TNF receptor family related protein (GITR) (42). In turn, pro-inflammatory cytokine tumor necrosis factor (TNF)- $\alpha$ might directly influence Treg function through the induction of protein phosphatase 1 (PP1) expression, which dephosphorylates the FOXP3 forkhead domain and changes its transcriptional function (45).

In addition to the central role played by cytokines, Hoeppli and colleagues also addressed other environmental stimuli that influence biological aspects of Treg, such as dietary metabolites, catabolites, and the host microbiota, focusing primarily on their implications for the development of new therapeutic interventions (46). The FOXP3 signaling cascade is summarized schematically in Figure 2.

\section{REGULATORY T CELL}

\section{Phenotypic Diversity}

Regulatory $\mathrm{T}$ cell is a specialized subset of $\mathrm{T}$ cells that induce suppression of the immune response to pathogenic agents as well as non-infectious targets, such as self-antigens and non-noxious external antigens. Thus, Treg maintains self-tolerance through suppression of the activation and expansion of autoreactive cells (47).

There are two different subsets of Treg (Figure 3). One consists of cells formed along thymopoiesis, resulting in a natural population of resident thymus-derived Treg (tTreg). These cells originate via the differentiation of TCR-stimulated naïve T cells or from functionally mature precursors that either do not express the IL-2 receptor $\alpha$ chain (CD25) or lose their ability to express it as a means to keep their suppressor function-although they may express it anew after stimulation by antigens and IL-2, thereby reactivating themselves as Treg $(48,49)$. Upon generation, these cells migrate to the periphery, where they perform their suppressor function, being essentially costimulated by CD28 to maintain cell survival and homeostasis (50). Most pTreg expresses high levels of $C D 25\left(C D 25^{\text {high }}\right)$, a small percentage expresses basal levels of this marker only $\left(C D 25^{\text {low }}\right)$, and both populations express FOXP3 (51).

The surface phenotype of tTreg is characterized by constitutive expression of markers $C D 4, C D 25$ (whence they are known as $\mathrm{CD}^{+} \mathrm{CD} 25^{+}$), selectin $C D 62 \mathrm{~L}$, integrin CD103, CTLA-, and GITR $(9,52-54)$. They might also express protein lymphocyte activation gene 3 (LAG-3); TNF receptor 2; and Toll-like receptors (TLRs) 4, 5, 7, and 8, among other molecules $(54,55)$, with differential expression of these markers between humans and mice (56). Basal expression levels of the IL-7 receptor (CD127) are characteristic of this cell population, and it is, therefore, used to distinguish them from other lymphocytes (57).

The second subset is composed of so-called pTregs, which are generated in the peripheral lymphoid organs from mature $\mathrm{CD} 4^{+}$ $\mathrm{T}$ cells under certain antigenic stimuli or in the presence of suppressor cytokines. In this population, $C D 25$ expression varies as a function of the local disease scenario and regulatory activity, and the suppressor ability of these cells is directly cytokine-dependent (9). Some authors have suggested that extrathymic Treg development might also be influenced by cytokine-modified dendritic cells (DCs) able to induce a state of anergy with suppressive properties in T cells (58).

Type 1 Tregs $(\operatorname{Tr} 1)$ are one of the most common populations of pTreg. They are characterized by significant production of the 


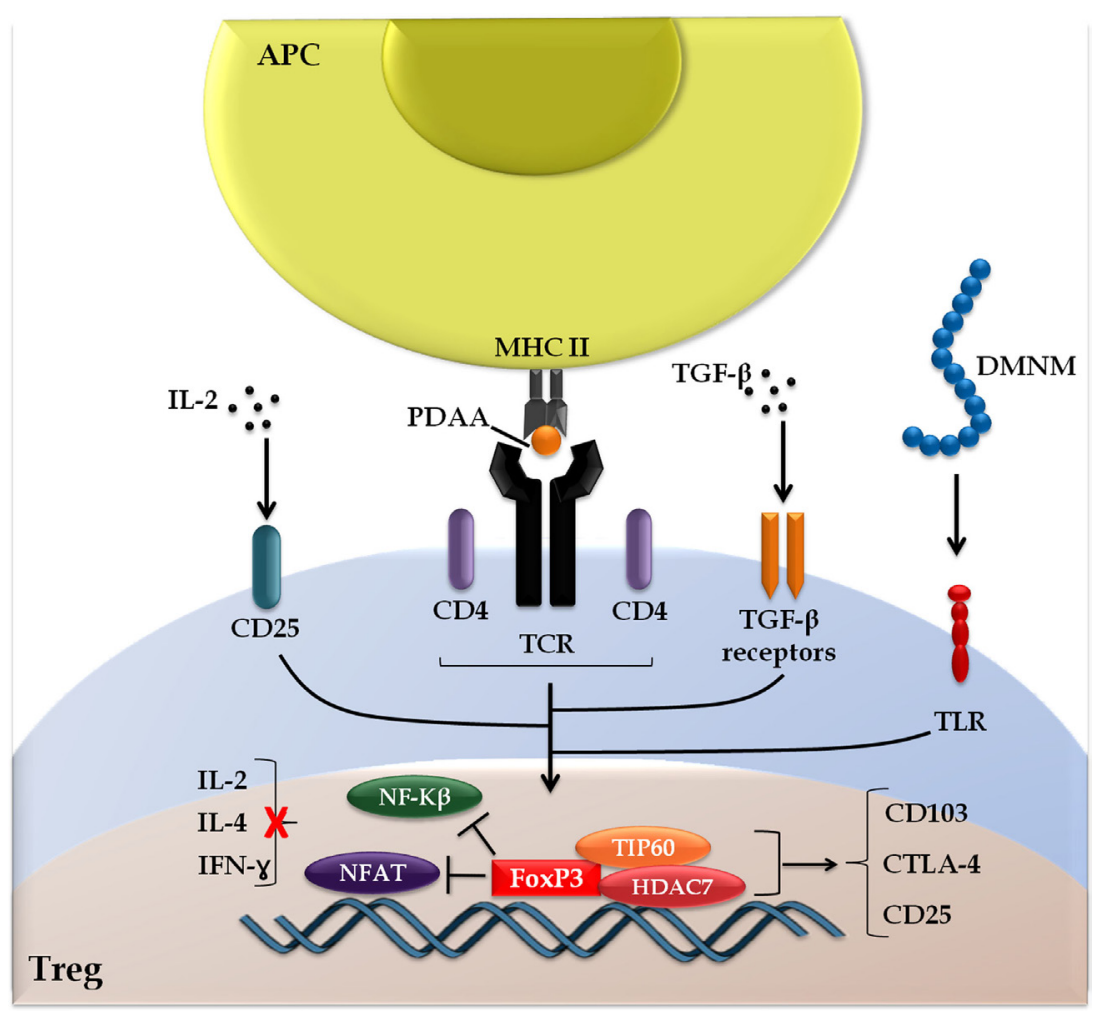

FIGURE 2 | Forkhead box protein 3 (FOXP3) signaling cascade. The induction of FOXP3 is initiated following the presentation of peptides derived from autoantigens (PDAA) through the interaction of the T cell receptor with major histocompatibility complex of class II (TCR-MHC II) on antigen-presenting cells (APC). Alternative stimuli include cytokines transforming growth factor (TGF)- $\beta$, interleukin (IL)-2, and metabolites derived from the intestinal microbiota (DMNM). FOXP3 interacts with chromatin remodeling factors (TIP60 and HDAC7), which facilitates the dynamics with target genes and prevents the interaction of transcription factors [nuclear factor kappa B (NF-k $\beta$ ) and nuclear factor of activated T cells (NFAT)] with activating cytokines cell response genes (IL-2, IL-4, and interferon- $\gamma$ ), but promotes the expression of genes linked to regulatory T cell (Treg) activation [CD103, cytotoxic T-lymphocyte-associated protein 4 (CTLA-4), and CD25], highlighting the double FOXP3 function as a transcriptional repressor and activator.

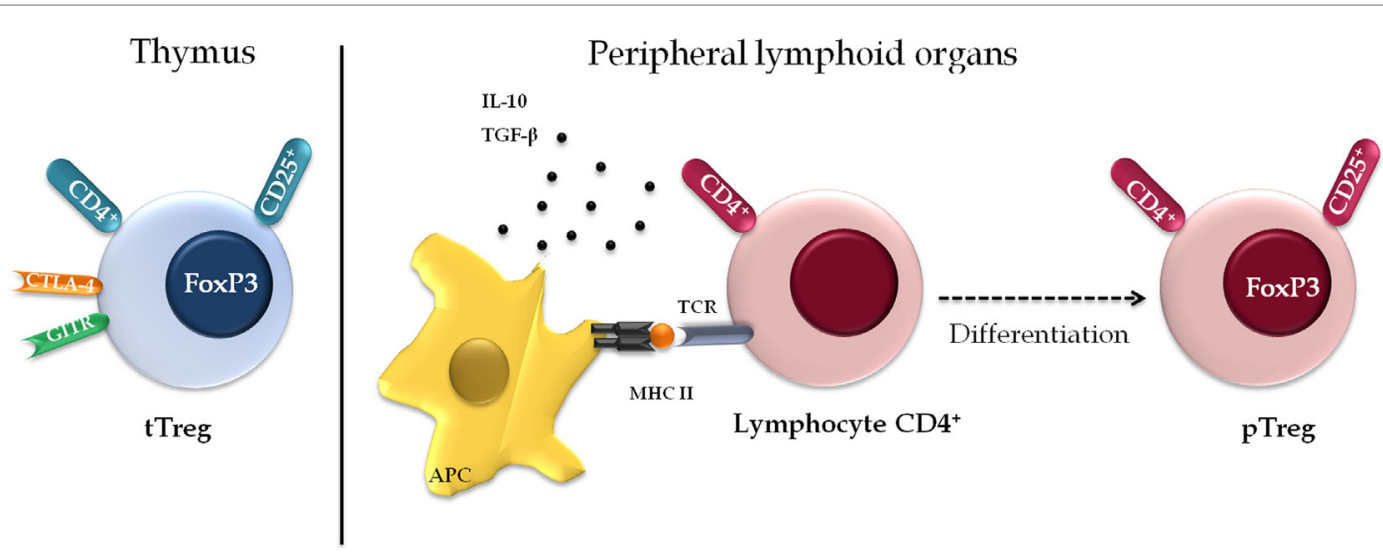

FIGURE 3 | Phenotypic diversity of regulatory T cell (Treg). There are two separate subsets of Treg. The first population of resident cells that is formed along the thymopoiesis and express constitutively markers including CD25, CD4, cytotoxic T-lymphocyte-associated protein 4, and glucocorticoid-induced TNF receptor family related protein. The second subset is formed by a peripheral Treg (pTreg) population that induces regulatory phenotype in the peripheral lymphoid organs, under specific conditions, antigenic stimulus, or suppressor cytokines.

cytokines IL-10, IFN- $\gamma$, IL-15, and TGF- $\beta$ and low production of IL-4 and IL-2 (59). Anergy and low cell proliferation are attributed to IL-10, which, together with IFN- $\alpha$, synergistically contributes to $\operatorname{Tr} 1$ cell differentiation (60). There is no marker specific for this population, although the repressor of GATA has been suggested as a potential candidate (61). 
Th3 cells are the second most frequent population of pTreg. This population originates from TGF- $\beta$-stimulated CD $4^{+} \mathrm{T}$ cells and plays a central role in oral tolerance to non-self antigens through secretion of IL-10 and TGF- $\beta$ (62). Other populations that might perform regulatory functions include the $\mathrm{CD} 4^{+} \mathrm{V} \alpha 14^{+}$ (NKTreg) (63), $\mathrm{CD}^{+} \mathrm{CD}^{2} \mathrm{RC}^{\text {low }}$ (64), $\gamma \Delta \mathrm{T}$ cells (65), among others.

\section{Mechanisms of Action}

Regulatory $\mathrm{T}$ cells induce immune suppression via a set of mechanisms that are clustered into four distinct models: cell-cell contact, cytokine secretion, competition for growth factors, and production of granzyme B (GzB) and perforin $(\mathrm{PRF})(66,67)$ (Figure 4).

Cell-cell contact is mediated by surface markers, such as CTLA-4 and LAG-3, in addition to other mediators, such as cyclic adenosine monophosphate (cAMP) (66). CTLA-4 regulates the catabolic enzyme indoleamine 2,3-dioxygenase through its interaction with costimulatory molecules CD80/86 present on antigen-presenting cells (APC), which interferes with the activation and proliferation of effector $\mathrm{T}$ cells through the reduction of free tryptophan (68). Additional evidence indicates that costimulation by CTLA-4 activates Treg to perform their suppressive action, while such activity is attenuated by a CD28mediated stimulating pathway. The balance between these two signals might be critical for the determination of the threshold of the immune response (69).

Lymphocyte activation gene 3 was found to modulate Treg function both in vitro and in vivo even when ectopically expressed (68). Treg might interfere with DC activation via interaction of LAG-3 with MHC class II (70); no similar role has been suggested for LAG-3 in the MHC-CD4 interaction despite its superior affinity (71).

Regulatory T cells increase cAMP levels in target cells through two mechanisms: direct release through gap junctions (72) and local adenosine production via CD39/73-mediated enzymatic hydrolysis of adenosine triphosphate (73). Interaction of adenosine with the A2A receptor elevates cAMP levels in target cells (74) with consequent inhibition of cell proliferation and differentiation as well as of the expression of cytokines, such as IL-2 and IFN- $\gamma$, via NF-kB blockade (75).

In addition to modulating Treg activation, secretion of TGF- $\beta$ and IL-10 is also involved in the maintenance of Treg suppressor activity. TGF- $\beta$ plays a key role in lymphocyte homeostasis; in Th1 cells, it inhibits the expression of the transcription factor T-bet, thus preventing cell differentiation (76). Similarly, it interferes with the response to IL-2 via downregulation of IL-2 receptor $\beta$ subunit expression (77). TGF- $\beta$ also influences Th2 cell differentiation through downregulation of the transcription factor GATA-3, a process directly or indirectly dependent on the transcription factor Sox4 (78). IL-10 suppresses T cell responses through downregulation of IL-2, IFN- $\gamma$, and granulocyte-macrophage colony stimulation factor (79). In addition, IL-10 modulates $\mathrm{B}$ cell function to promote immune tolerance during allergy, which is evidenced through the induction of immunoglobulin IgG4 and the suppression of IgE (80).
By constitutively expressing CD25, Tregs are potential competitors for IL-2 relative to their target cells. Lack of growth factors causes apoptosis of target cells both in vivo and in vitro through the B cell lymphoma 2 protein/Bim pathway and independently of PRF/Fas (81). Changes in suppression might occur following the addition of exogenous IL-2 or reinforcement of its endogenous production in vitro (82). Experimental models narrow the relationship of IL-2 to Treg suppressor activity by showing that IL-2 blockade, and consequent loss of stimulation by this pathway, can induce conventional $\mathrm{T}$ cells to a stronger cellular response to autoantigens or to environmental antigens (83).

Other authors have emphasized an additional mechanism of suppression in $\operatorname{Tr} 1$ lines characterized by cytolytic activity on target cells of myeloid origin and mediated by GzB and PRF and dependent on MHC class I, CD54, CD58, CD155, and CD122. The GZB induces target cell apoptosis via caspase or via BID (67).

\section{Treg: Immune Tolerance and Suppressive Response}

The first relevant steps toward the elucidation of the immune tolerance were made at the turn of the 1970s. First, Nishizuka and Sakakura reported in 1969 the occurrence of autoimmune disorders in young normal mice subjected to thymectomy. Then, in 1973, Penhale and colleagues found that normal adult mice subjected to thymectomy and irradiation developed autoimmune thyroiditis $(84,85)$. Several interpretations were suggested for these phenomena, one of which addressed the alteration of T cell homeostasis, leading to uncontrolled proliferation of autoreactive cells (86). However, the following series of studies indicated that Treg depletion was a plausible mechanism for loss of immune tolerance and consequent development of chronic autoimmune diseases $(87,88)$.

After the association of mutations in Foxp3 with the immunological status of the mutant strain scurfy (sf), it was possible to discuss the relevance of genetic mechanisms in the control of immunological homeostasis (89). Subsequently, studies reported the importance of Foxp3 gene expression in the development and function of Treg both in the thymus and peripherally (13, 90). Therefore, Treg plays an essential role in the suppression of the immune response to a wide variety of self- (autoimmune response) and non-self-antigens and needs to be further investigated as a specific therapy for immune tolerance $(91,92)$.

Regulatory $\mathrm{T}$ cell is involved in immune phenomena occurring in a wide variety of organs. In a mouse model of liver injury induced by concanavalin A (Con A), a mitogenic lectin, tolerance was due to increased IL-10 production by Treg (93). In a later study, the frequency of Treg in the liver increased after Con A injection, with this population being phenotypically different from that in the spleen, as it characteristically exhibited increased Foxp3, CTLA-4, GITR, and CD103 expression. The authors further suggested that Treg activity depended on TGF- $\beta$ because blockade of TGF- $\beta$ signaling increased susceptibility to liver injury (94).

The intestinal microenvironment is a preferential site for development of Treg induced by microbiota-derived antigens. Suppression of the immune response has effects on local 


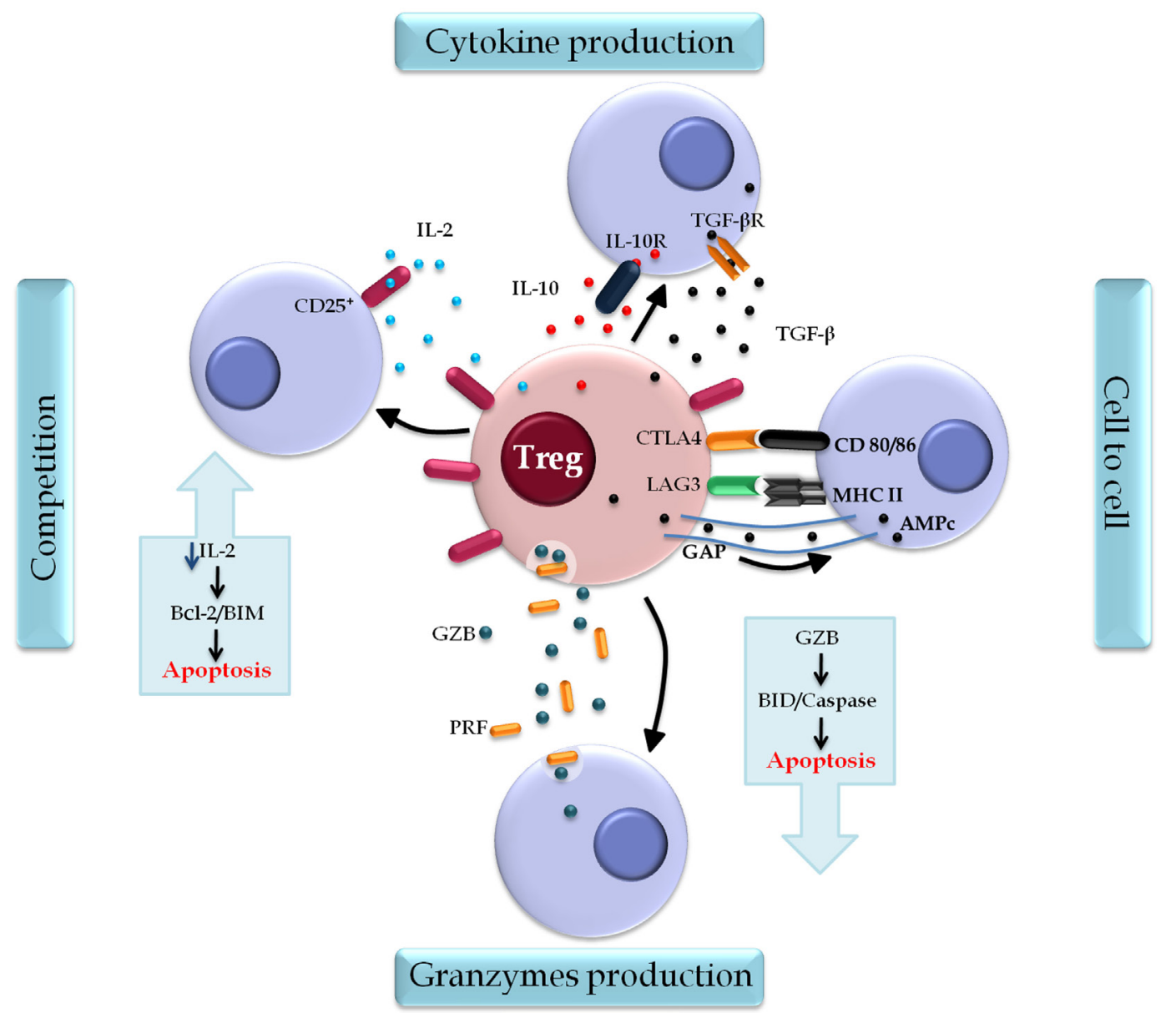

FIGURE 4 | Regulatory T cell (Treg) action mechanisms. Tregs induce immune suppression by four classical mechanisms: the contact cell-to-cell is mediated by surface markers cytotoxic T-lymphocyte-associated protein 4 (CTLA-4) and lymphocyte activation gene 3 (LAG-3) that interact, respectively, with molecules $\mathrm{CD} 80 / 86$ and $\mathrm{MHC}$ II on the target cells, regulating cell function. AMPc is also a mediator of this mechanism, which is released directly through the gap junctions and inhibits the proliferation and differentiation of the target cell. Cytokine production, in which transforming growth factor (TGF)- $\beta$ and interleukin (IL)-10 modulate the activation and function of Treg. Competition for growth factors, in particular IL-2, the constitutive expression of CD25 on Treg, and their deprivation induce target cell to apoptosis through the B cell lymphoma 2 protein (Bcl-2)/BIM pathway. A fourth mechanism is found in lineages Type 1 Treg that secrets Granzyme B (GZB) and perforin (PRF) that act specifically in myeloid precursors. The cytolytic activity of GZB in target cells induces apoptosis by caspases or BID pathway.

homeostasis, as any breakdown of the Treg network causes chronic inflammation (95). In this context, IL-23 is suggested as a limiting factor of the regulatory mechanisms of Treg from the intestinal inflammatory response. The IL-33/ST2 pathway activation is notorious for the adaptation of Treg to inflamed tissue and maintenance of immune regulation (96), in fact, blockade of the ST2 pathway may affect the activation of Treg, as shown in mice with insulin resistance associated with obesity, which thus affects the adipoimmune profile in the pathological condition (97). However, studies show that the transferred Foxp $3^{+}$or $\mathrm{CD}_{45 \mathrm{RB}^{\text {low }}}$ and $\mathrm{CD} 45 \mathrm{RB}^{\text {low }} \mathrm{CD} 25^{+}$Treg with regulatory potential were sufficient to prevent Th1- and Th17-mediated intestinal inflammation, as shown in a model of colitis in mice (98).

Regulatory $\mathrm{T}$ cell also participates in the maintenance of skin immune homeostasis, representing $10 \%$ of all $\mathrm{T}$ cells in the normal skin. The expression of $\mathrm{E}$ - and P-selectin ligands $(E-/ P$ - Lig) is indicative of Treg kinetics across the epithelial tissue. Constitutive recirculation of Treg through the skin is severely impaired in the absence of the enzyme FuT7, and blocking Treg migration to the skin results in severe tissue-specific inflammatory disease (99). Memory Treg (mTreg) is maintained in the tissue for long periods, even post antigenic stimulus, but its suppressive capacity is increased when the antigen is expressed again, thus limiting the severity of inflammatory or autoimmune reactions in the tissue. Treg naturally passes through the phases of generation, proliferation, and differentiation in specific memory populations, which express high levels of activated Treg markers, but with low expression of $I L-2$ and $I L-7$, indicating them as a final stage of differentiation of Treg (100-102).

In the oral mucosa, Treg conversion is induced by antigens and reinforced by TGF- $\beta$ and retinoic acid. The reinforcement by retinoic acid results in up-regulation of integrin $\alpha 4 \beta 7$ and chemokine CCR9, whereby Treg accumulates in the gut-associated lymphoid tissue, with cytokine secretion being one of the main mechanisms 
of maintaining oral tolerance, in particular IL-10 and TGF- $\beta$ (103). The oral Treg population is characterized by expression of latency-associated peptide, which is non-covalently associated with the amino-terminal domain of TGF- $\beta$, forming a latent TGF$\beta$ complex (104). Although also induced during oral tolerance and mainly related to the suppression of the Th1/Th17 response, the $\mathrm{CD}^{+} \mathrm{CD} 45 \mathrm{RC}^{\text {low }}$ Treg subpopulation (64) is less prevalent in the oral mucosa than $\mathrm{CD}^{+}$cells $(105,106)$.

Molecular abnormalities in autoreactive Treg might trigger resistance to Treg-mediated suppression and the breakdown of tolerance. One study found that hyperreactive $\mathrm{T}$ cells of mice lacking Clb-b, a protein that participates in CD28 activation, were resistant to Treg-mediated suppression in an in vitro model due to increased secretion of IL-2 following TCR stimulation, which neutralizes Treg-mediated suppression (107).

\section{Immunoregulatory Role of Treg in Transplants}

The immune response plays a key role in graft rejection; for this reason, much effort has been devoted to the development of protocols to induce immune tolerance in this setting (108). Tregs stand out because their primary and homeostatic regulatory mechanisms are necessary to prevent immune graft rejection (109).

In experimental models, the high frequency of $\mathrm{CD}^{+} \mathrm{FOXP}^{+}$ Treg exhibited by recipients of allogeneic bone-marrow transplants was found to be inversely proportional to the incidence of deaths by acute graft-versus-host disease (GVHD), which emphasizes the role of Treg as mediators of immune attenuation. The prognostic value of Treg at the onset of GVHD is directly related to the improvement of the clinical status of patients; however, the use of immunotherapy agents, such as calcineurin inhibitors, might impair Treg expansion and function (110-112).

Al-Wedai and colleagues found that the frequency of Treg was significantly lower in patients with chronic rejection compared to stable kidney transplants, which emphasizes the role of Treg in local immune tolerance (15). In a model of adoptive Treg transfer between mice, the number of Tregs gradually increased in the recipients following injection of allogeneic Treg every 2 weeks. This finding lends support to the hypothesis that Treg generated ex vivo can act as a therapeutic vaccine to induce suppression in the host (113). While the frequency of Treg after transplantation decreases over time, the suppressive capacity of this cell population remains unchanged or increases (16).

Different Treg populations with different transient roles and in specific concentrations are likely needed for the maintenance of transplantation tolerance. The coexistence of natural and $\operatorname{Tr} 1$ was demonstrated in a mouse model of induced tolerance after pancreatic islet transplantation. While the frequency of tTreg was significantly higher at the onset of graft rejection and then returned to physiological levels soon after, the frequency of $\operatorname{Tr} 1$ cells remained high over a long period of time. Differences in location and migration, duration of action after transplantation, and maintenance of long-term tolerance were also observed between these cell populations $(114,115)$.
Stimulation with IFN- $\gamma$ generates conditioned alloreactive Tregs, which are phenotypically characterized by $C D 25$, CD62L, and FOXP3 expression. In addition, they inhibit skin graft rejection and vasculopathy associated with posttransplant arteriosclerosis by controlling reactive $\mathrm{T}$ cell infiltration into the transplanted organ. In vitro production of these cells might result in clinical benefits via $\mathrm{T}$ cell regulation after transplantation (116-118).

Immunosuppressive drugs are used to reduce the occurrence of episodes of graft rejection. Rapamycin (also known as sirolimus), a macrolide antibiotic that inhibits cell cycle progression in $\mathrm{T}$ cells, might induce conversion of peripheral $\mathrm{CD}^{+}{ }^{+} \mathrm{CD} 25^{-} \mathrm{T}$ cells to $\mathrm{CD} 4{ }^{+} \mathrm{FOXP} 3^{+}$Tregs potentially able to suppress effector $\mathrm{T}$ cell proliferation while maintaining their antigenic specificity (119). Sirolimus favorably regulates the Th17/Treg axis; this was demonstrated by suppression of Th17 and upregulation of Treg, which contribute to kidney graft acceptance (120). Clinical data point to the improvement of chronic nephropathy and long-term kidney function as well as to the reduction of vascular abnormalities in patients given sirolimus as an immunosuppressant (121).

Calcineurin inhibitors significantly reduce the occurrence of acute episodes of kidney graft rejection compared to azathioprine (122) [a synthetic purine analog with immunosuppressive properties (123)]; however, they cause considerable long-term side effects, including nephrotoxicity and graft failure (124). Efforts are currently devoted to the identification of markers of graft acceptance likely to contribute to minimize immunosuppression. The role of the mTreg/Treg balance in the dynamics of treatment is one of the main issues requiring elucidation (125).

\section{RELEVANCE OF FOXP3 AND TREG IN PATHOLOGICAL CONDITIONS}

\section{Autoimmune Diseases}

As Tregs are clearly associated with the maintenance of immune homeostasis, one may safely assert that, in autoimmune diseases, these specialized cells participate in complex regulatory mechanisms aimed at recovering the natural pattern of immunity (Figure 5).

In a model of transgenic mice (named SFZ70) reactive to skin autoantigens, TCR-autoantigen stimulation induced the development of active Treg able to migrate to the skin and inhibit the expression of tissue-homing molecules and pro-inflammatory cytokines by conventional T cells (126). Thus, one might assert that the reverse is also true, i.e., abnormalities in the function of different Treg populations contribute to the genesis of autoimmune diseases. For instances, Treg function is significantly reduced in patients with multiple sclerosis compared to healthy individuals (127) as well as the reduction of FOXP3 expression (128). When stratified for the severity of sclerosis, an inverse relationship is suggested between the frequency of Treg and the disease score (129), indicating that the loss of immune tolerance may contribute to the emergence of autoimmunity against components of the central nervous system, although the frequency of these cells does not change significantly when compared 


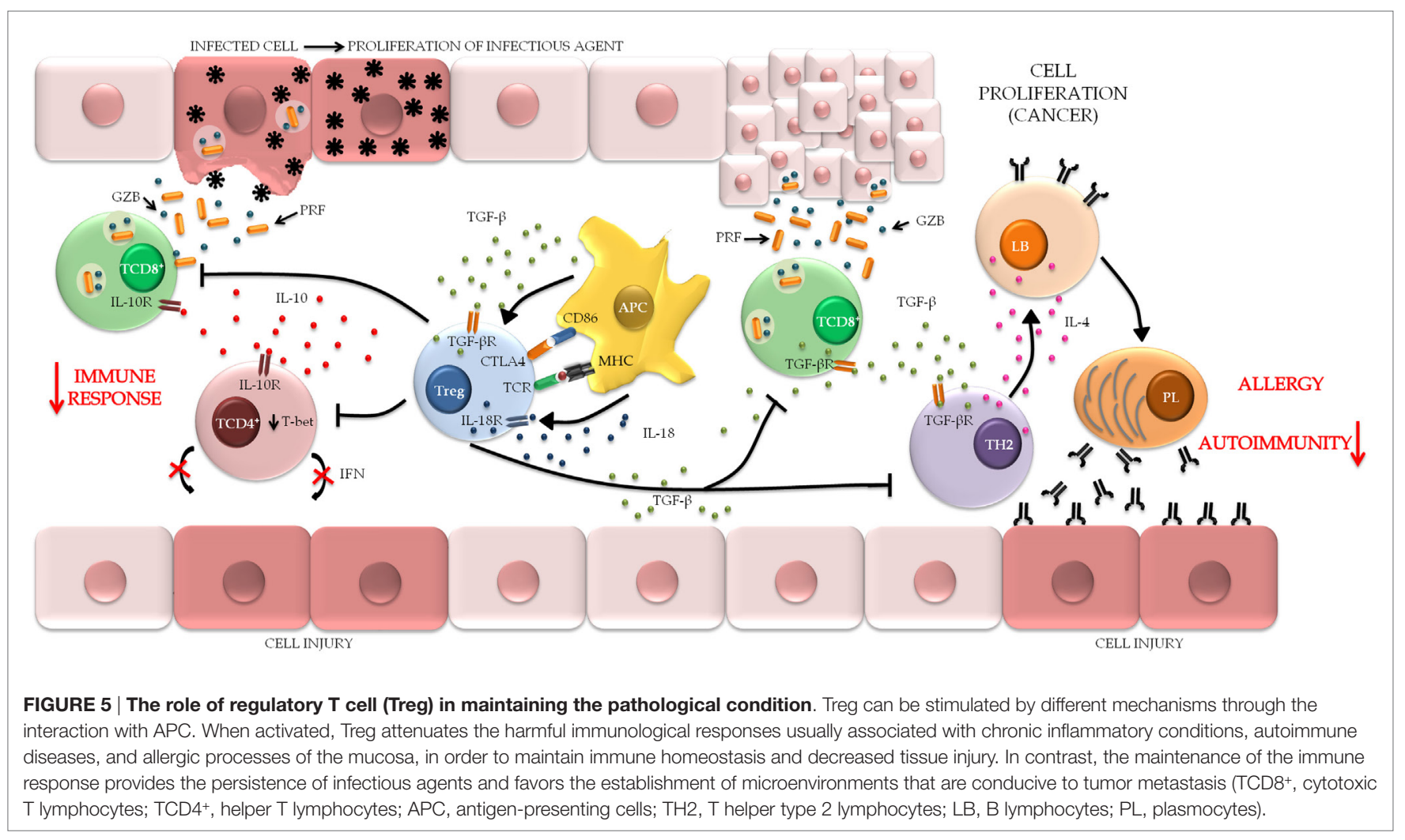

to healthy individuals, or between the cerebrospinal fluid and the peripheral blood of these patients (12). The proportion of Treg reflects on clinically evident sexual dimorphism in the incidence of sclerosis, in which women show a higher frequency of these cells in cerebrospinal fluid (130). Therapeutic regimens have distinct functional effects on the Treg population, whereas fingolimod treatment does not alter the frequency of these cells (131), maintenance of anti-CD25 monotherapy substantially reduces the frequency of Treg without altering tolerance in the central nervous system (132).

The conclusion about the frequency of Treg in rheumatoid arthritis (RA) remains conflicting. While studies report a significant increase in Treg in peripheral blood and synovial fluid of RA patients (133), other studies show a decrease in the proportion of these cells in patients' blood circulation (134). The discrepancy of these results may be related to the diversity of Treg phenotypes that manifest distinctly depending on the stage of the disease: there is a decrease in the $\mathrm{CD} 4^{+} \mathrm{CD} 25^{\text {high }}$ phenotype in the early stage of the disease (135), while the $\mathrm{CD} 4^{+} \mathrm{CD} 25^{+} \mathrm{FOXP}^{+}$is not altered in the inactive phase (136), and the percentage of Treg cells expressing the CD45RO memory phenotype increases both synovial fluid and peripheral blood independent of the degree of disease activity (137), indicating that some functional Treg phenotypes preserve regulatory activity as a way to mitigate collateral damage, although, in a general context, an exacerbated immune response prevails in RA (138). In this context, treatment with TNF-suppressing drugs, such as infliximab, helps in the recovery of Treg number and functionality (139). Research also points out that histone deacetylase inhibitor drugs may induce FOXP3 expression and the suppressive capacity of Treg in vitro, suggesting that these drugs may in future be included in therapeutic regimens for autoimmune and inflammatory diseases (140).

Evidence shows that the reduction of Treg frequency is one of the factors related to the clinical manifestations of systemic lupus erythematosus (SLE) (141), and the suppressive function of these cells depends on the stage of the disease (142), as demonstrated in thrombotic thrombocytopenic purpura associated with SLE, whose $\mathrm{CD} 4^{+} \mathrm{CD} 25^{+}$phenotype was correlated with disease severity (143); and in patients with lupus nephritis, where the high expression of FOXP3 was associated with the systemic and histological activity of the disease and could be used in the risk stratification of the disease, suggesting FOXP3 as an analytical biomarker of autoimmune activity (144). Other studies, however, show that the number of Tregs increases in SLE as a mechanism contrary to the establishment of the pro-inflammatory condition (145). New therapeutic platforms are being explored in order to aid in the functional reestablishment of Treg in lupus. In double knockout models for DEF-6 and SWAP-70, it is proposed that both factors represent important regulatory proteins that maximize the ability of Treg to cope with the chronic inflammatory condition (146). As well, mesenchymal stem cells can produce immune tolerance-inducing molecules, such as TGF- $\beta$, both in vivo and in vitro, which highlights the potential of these cells as a future therapeutic scheme (147).

Forkhead box protein 3 was suggested as an analytical biomarker of autoimmune activity. In patients with lupus nephritis, high FOXP3 expression was associated with systemic and histological disease activity and could therefore be used for risk 
stratification (144). The literature points to mutations in FOXP3 as the main genetic factor that interferes with Treg function; however, one patient with non-immunodeficiency, polyendocrinopathy, and enteropathy X-linked (IPEX) autoimmune enteropathy had no mutations in the FOXP3 locus and did not exhibit chronic reduction of Treg in the bloodstream or accumulation of FOXP3 ${ }^{+}$ Treg in the inflamed duodenum during the active stage of disease, which could have contributed to the loss of local immune control. Global lymphocytopenia affecting various $\mathrm{T}$ cell populations was due to defective production and export of thymic cells, which lends support to the hypothesis that the disease has an autosomal pattern of inheritance (148).

The fact that the liver microenvironment induces immune tolerance partly via generation of Treg leads one to question the possible participation of these cells in autoimmune hepatitis (AIH). Selective autoantigen stimulation is known to lead to Treg generation in sinusoidal endothelial cells in vivo, which is considered to be an effective anti-autoimmune mechanism (149). In a mouse model of primary biliary cirrhosis, which is similar to the human disease, sf mice were used to demonstrate that abnormal Treg function is accompanied by exacerbation of $\mathrm{CD}^{+} \mathrm{T}$ cellmediated bile duct autoreactive damage (150). In human AIH, although numerically and functionally abnormal, Tregs reduce the production of Th1 cytokines and promote secretion of Th2/ Th3 cytokines via cell-cell contact (151). Reduction of Treg might occur in response to treatment with steroids/azathioprine, which are the recommended drugs because they preserve immune regulation and promote long-term control of AIH $(152,153)$. However, some studies with discrepant results have suggested that the frequency and function of Treg are not affected in AIH, although they might be correlated with disease severity. AIH progression might be due to resistance to Treg activity, inflammatory stimuli too strong for the intrahepatic Treg, or lack of identification of liver autoantigens, with consequent absence of tissue suppression (154).

\section{Allergies}

In the traditional model of IgE-mediated allergic responses, imbalance of the Th2 profile triggers chronic inflammation typical of the acute response on skin or mucosal surfaces, and deviations in this proportion distinguish healthy and allergic responses (155) (Figure 5). In a mouse model of atopic dermatitis, increased expression of Th2 cytokines and elevated IgE levels exhibited inverse correlations with Treg depletion (156). Similar phenomena were detected during the sensitization phase in a murine model of experimental allergic airway inflammation, which suggests that Treg-mediated maintenance of tolerance against allergens occurs spontaneously as early as the sensitization phase (157). In humans, the proportion of $\mathrm{FOXP} 3^{+} \mathrm{CD} 25^{\text {high }}$ Treg in umbilical cord blood and early childhood exhibited positive correlations with sensitization at the age of 18 and 36 months. Nevertheless, more complex studies are needed to confirm whether the Treg proportion precedes sensitization and whether high levels of Treg might interfere with the natural development of $\mathrm{T}$ cells during childhood (158). Regarding seasonal allergy in humans, the presence of FOXP $3^{+}$Treg in the nasal mucosa after immunotherapy is associated with the clinical efficacy of treatment (159).
Based on the functional characteristics of $\operatorname{Tr} 1$ cells, some authors have asserted that $T h 2$ regulation depends on the secretion of IL-10 and TGF- $\beta$ and expression of CTLA-4 and programmed death-ligand 1 (155). However, no significant differences were found in TGF- $\beta$ expression between children with and without food allergies, which might be considered a phenotypic singularity of Treg specifically involved in this type of allergy (160). Singular phenomena were also detected in patients subjected to allergen-specific immunotherapy, as the frequency of Treg did not depend on the nature of the allergens but rather on the degree of severity of clinical symptoms and the specific location of the allergic reaction (161).

\section{Cancer}

Induction of Treg within the tumor microenvironment has been suggested as a mechanism likely to cause impaired anticancer immunity, and the expansion of this cell population might be considered a true hindrance to the efficacy of immunotherapy (162) (Figure 5). Radiation-induced immunosuppression is an example of Treg induction giving rise to a microenvironment both susceptible to and permissive for cancer and mutagenesis (163).

Studies have shown an association between Treg infiltration into the liver and recurrence of tumor metastases and multicentric cancer after hepatic resection (164), coinfiltration by FOXP3 ${ }^{+}$ Treg and $\mathrm{B} 7-\mathrm{H} 1^{+} \mathrm{PD}-1^{+} \mathrm{T}$ lymphocytes with high-risk breast cancer (165), density of FOXP3 ${ }^{+}$lymphocytes with lymph node metastases of pancreatic cancer (166), and expression of FOXP3 and $p 16^{I N K 4 a}$ with progression of cervical cancer, more specifically with lymph node metastasis (167). Divergences on the prognostic value of Treg were discussed in the meta-analysis of Zhao and colleagues. Upon ignoring the possible combinations of various Treg markers, these authors concluded that Treg infiltration into the lung tissue did not affect the survival, relapse, or global survival rates of patients with non-small-cell lung cancer. However, inclusion of studies that analyzed FOXP3 alone or in combination with other markers showed that global survival was significantly associated with cancer (168). New therapies based on reducing or inhibiting FOXP3 expression to reduce abnormal Treg proliferation stabilize the tumor microenvironment and block the immune escape of tumors, and consequently metastasis needs to be discussed (169).

Other Treg subpopulations might also be induced within the tumor microenvironment. The human ovarian carcinoma SK-OV-3/A2780 cell line is able to convert in vitro $\mathrm{CD}^{+} \mathrm{T}$ cells into a $\mathrm{CD}^{+}$Treg phenotype that promotes tumor progression through immune regulation partially mediated by TGF- $\beta 1$ and IFN- $\gamma(170)$.

In molecular terms, signet ring cell carcinoma cells might assume functions similar to those of Treg, as evidenced by FOXP3 expression, which enables them to escape immune surveillance and induce lymph node metastases (171). In stomach cancer, hypoxia potentiates Treg-mediated immune escape through the regulation of cytokines, TGF- $\beta 1$ in particular (172). The neuropilin 1 (NRP1) is suggested to be another marker correlated with Treg carcinogen maintenance. Vascular endothelial growth factor produced by the tumor induces the migration of Treg NRP1+ 
to the intratumoral environment, resulting in a local immunosuppression favorable to tumor growth (173). Additionally, the cofactor semaphorin-4a interacts with NRP1 activating the threonine serine protein kinase $\mathrm{B} /$ phosphatase and tensin homolog phosphorylation pathway, which assists in maintaining the cell stability of intratumoral Treg (174).

However, the FOXP3 gene may also act as a tumor suppressor in cancer models. In breast cancer, for example, both control of $H E R-2 / E r b B 2$ oncogenes expression and the marked frequency of mutant isoforms of FOXP3 indicate that FOXP3 is an important suppressor of the carcinogenic condition (175); in a study in which $68.5 \%$ of the patients with prostate cancer expressed FOXP3, FOXP3 behaved as a tumor suppressor. According to the authors, these findings suggest that suppression of malignant transformation is due to FOXP3 repression of $c-M Y C$, an oncogene traditionally expressed in tumors (176).

\section{Cardiovascular Diseases}

Atherosclerosis is a chronic inflammatory cardiovascular disease that begins with infiltration of immune cells, which contributes to the development of typical lesions (177). Within this context, Tregs stand out as an intrinsic atheroprotective mechanism due to their ability to suppress the inflammatory response, as was discussed above (Figure 5).

Experimental studies with mice have found that Treg transfer hinders the development of atherosclerotic plaques and, reciprocally, that Treg depletion is associated with worsening of lesions (178). Studies with chimeric (DEREG/Ldlr ${ }^{-1-}$ ) mice both confirmed the relationship between Treg and atherosclerosis and also showed that depletion of these cells worsened hypercholesterolemia in the experimental animals, thus emphasizing the impact of immune mechanisms on metabolic events (179). Administration of IL-2 considerably increased the frequency of Treg and suppressed the IL-10-dependent Th1/2 effector response, with a 39\% reduction of atherosclerotic plaque formation. While treatment did not induce regression of preexisting plaques, it significantly enhanced lesion stabilization (180).

Mor and colleagues found that Tregs were significantly lower in patients with acute coronary syndromes compared to patients with stable angina and healthy controls. Curiously, the Treg number was similar between the latter groups, albeit with comparatively different suppressor functions (181). Similar phenomena have been described for atherosclerotic plaques, although the frequency of Treg was higher among patients with more advanced lesions (182).

Downregulation of CD1a (of DCs) and FOXP3 occurs in different clinical subsets of coronary artery disease (183). The tolerogenic profile resulting from Treg (CTLA-4) and DC (CD86) interactions indeed increases atheroprotective effects via cell-cell contact (184).

\section{Viral Infections}

Models based on the transfer or removal of Treg from hosts allow measurement and evaluation of their roles in the pathogenesis of viral infections (185). Using such methods, it was recognized that Tregs interact with and modulate antiviral response pathways, particularly in the case of chronic and persistent infections (Figure 5); the range of mechanisms through which viruses trigger Treg responses remains a subject of current debate (186). Modulatory molecular mechanisms have been described for herpes simplex virus type 1 (HSV-1) infection; interactions between viral glycoprotein $\mathrm{HSVgD}$ and herpes virus entry mediator (HVEM) were found to promote Treg proliferation; in turn, preactivated Tregs upregulate HVEM, inducing positive feedback between both (187), although other authors argue that Treg may unexpectedly facilitate early immune responses in HSV-infected mice by orchestrating homing of effector cells to the site of infection (188). Methyltransferase SMYD3 was suggested as a primary epigenetic marker of FOXP3 regulation in mice infected with respiratory syncytial virus (189). Upon infection with the porcine reproductive and respiratory syndrome virus (PRRSV), high Treg frequency in association with viremia emerged as a promising parameter for future studies of the immunobiology of PRRSV infection, although no specific molecular pathway has been established (190). However, in infection with rotavirus, Tregs were not found to have an impact on rotavirus clearance or specific antibody levels, although the hypothesis that Treg depletion might interfere with IgA titers at the peak of disease cannot be ruled out (191).

Regulatory $\mathrm{T}$ cells are generated intrathymically in response to a peptide derived from the influenza virus hemagglutinin and then undergo functional specialization along the course of the immune response (192). In the early stages of infection, influenza virus induces a massive regulatory response characterized in ex vivo models by robust Treg suppressor activity preceding the establishment of adaptive immunity (193). In aged mice, for instance, a high frequency of tTreg interfered with the primary immune response to flu (194). The data available for secondary infections support the hypothesis that there are antigen-specific mTregs that regulate the immune response and limit the immunopathology of disease to a degree similar to that of primary infection (195).

Controversial findings indicate that, rather than suppressing, Tregs indirectly promote $\mathrm{B}$ cell and $\mathrm{T}$ follicular helper $\left(\mathrm{T}_{\mathrm{FH}}\right)$ responses to influenza through reduced availability of IL-2 (196). Immunization of $\mathrm{BALB} / \mathrm{c}$ mice with a prototype of inactivated influenza PR8/A/34 virus vaccine expanded the Treg pool but had no effect on the specific B cell response, although it effectively suppressed helper and memory T cells (Tmem) induced by vaccination (197).

The increased frequency of Treg found in infection with the human T-lymphotropic virus 1 (HTLV-1) lends support to the alleged advantage of these cells as hosts, as they contribute to viral expansion due to their hyperproliferative profile, while their immunosuppressive potential enables them to play a pivotal role in immune escape $(198,199)$.

Data on adult $\mathrm{T}$ cell leukemia indicate that some leukemia cells might adopt a suppressor profile similar to that of Treg when originating from $\mathrm{FOXP}^{+}$precursors (200). The low frequency of Treg in HTLV-1-associated infective dermatitis is related to the maintenance of a microenvironment permissive for lymphocyte expansion and establishment of typical lesions (201). Reduced CTLA-4 and GITR expression in Treg might influence 
the paradoxical state defined by high Treg frequency with persistence of the inflammatory profile, which is characteristic of tropical spastic paraparesis (also known as HTLV-1-associated myelopathy) (199). Potential dysfunction of Treg in human immunodeficiency virus (HIV)/HTLV-1 coinfection-associated neuropathy is due to transient FOXP3 expression, which does not convey regulatory properties (202). Such a complex scenario is determined by viral regulatory proteins. HTVL-1 basic zipper factor, for instance, might interact with the SMAD 2/3 and P300 pathways, which results in increased FOXP3 expression (203). However, Tax causes a reduction in FOXP3 expression through inhibition of the TGF- $\beta /$ SMAD pathway (204) and demethylation of the Treg-specific demethylated region gene (205).

Regulatory T cells are cell reservoirs for HIV; their suppressive capacity is not influenced by the virus, as the inhibition of $\mathrm{CD} 4^{+}$ $\mathrm{T}$ cells is preserved and might contribute to virus propagation in the lymph nodes (206). Follicular Treg cells $\left(\mathrm{T}_{\mathrm{FR}}\right)$ help in this process because their expansion into secondary lymphoid tissues is related to the inhibition of $\mathrm{T}_{\mathrm{FH}}$ proliferation and IL-4 and IL-21 production in infections caused by HIV and simian immunodeficiency virus (207). Data suggest a dominant mechanism of suppression by Treg that might reduce in vivo antiviral responses that participate in the inability to eradicate HIV infection; however, ex vivo studies have not been able to corroborate this hypothesis (208). Reductions in FOXP3 methylation levels were detected in patients undergoing antiviral therapy, which altered gene expression and increased Treg infiltration of the colonic mucosa (209). However, other studies did not find correlations between FOXP3 expression and the highly active antiretroviral therapy (210); thus, the participation of Treg in therapeutic interventions remains controversial.

The fact that some patients with acute hepatitis B virus (HBV) develop persistent infection associated with $\mathrm{T}$ cell hyporeactivity and dysfunction suggests a contribution of Treg in this infection (211). The frequency of Treg fluctuates along the course of acute infection, and the cells exhibit greater suppressor activity against HBV-specific T cells compared to non-specific responses (212), although they do not seem to influence the development of immunological memory (213). High Treg frequency was also reported in the blood and liver tissue of individuals with chronic $\mathrm{HBV}$ infection, as was increased proliferation of HBV-specific $\mathrm{T}$ cells after the Treg frequency decreases. These cells are directly related to the envelope antigen $(\mathrm{HBeAg})$ and TGF- $\beta$ serologic status, and their distribution across the body varies according to the clinical status of patients $(212,214,215)$.

In hepatitis $\mathrm{C}$ virus (HCV) infection, Tregs are associated with viral persistence and weak $\mathrm{T}$ cell responses (216). Studies investigating the relationship of Treg with hepatitis $C$ have emphasized one particular role played by the various Treg populations in the pathogenesis of infection, which is especially relevant for the host's protection against tissue damage (217-219). Interestingly, in one study, HCV-infected patients with normal alanine aminotransferase levels exhibited higher frequency of HCV-specific TGF- $\beta$-producing Treg and reduced liver inflammation (220). FOXP3 expression was found to be elevated in patients with liver cirrhosis and was associated with the expression of other immunogenetic markers, such as FAS and its receptor FASL (221).

\section{Bacterial Infections}

The role of Treg in the immune response is considered contradictory, in as much as they may facilitate pathogen persistence by regulating the suppression of effector responses potentially noxious for tissues (222) (Figure 5). As an example, the frequency of tTreg significantly increased in the blood and spleen of mice subjected to experimental sepsis, which was likely correlated with IL-6 expression (223). Furthermore, expression of TLRs in Treg is indicative of an additional molecular mechanism for the maintenance of immune regulation (224). Attempts at reestablishing immune homeostasis, in sepsis notwithstanding, indicate that regulatory mechanisms are not restricted to the pathological condition and thus contribute to immune dysfunction as well as the progression of disease (225).

The participation of Treg in mycobacterial infections has been analyzed. In patients with active tuberculosis, increased frequency of Treg was found to be associated with suppression of IFN- $\gamma$ by Th1 cells, with consequent reduction of tissue damage (226). FOXP3 $3^{\text {low }}$ Treg inhibited the growth of Mycobacterium tuberculosis in human macrophages and mice through production of a rho GPD dissociation inhibitor (D4GDI), thus contributing to the development of effective immunity against the pathogen (227). Holla and colleagues found that SHH-PI3K-mTOR-NF-kB signaling in DCs was necessary for Mycobacterium bovis BCG-specific pTreg expansion, while NOTCH1 signaling hindered the ability of infected DCs to expand Treg. As a result, these authors emphasize the ability of mycobacteria to regulate signaling molecules involved in the immune response, consequently determining the latter's functional direction (228).

Helicobacter pylori exerts a similar pressure on DC maturation, resulting in their conversion to the semimature and tolerogenic phenotype $\mathrm{CD} 11 \mathrm{c}^{+} \mathrm{MHCII}{ }^{\text {hi }} \mathrm{CD} 80^{\mathrm{lo}} \mathrm{CD} 86^{\mathrm{lo}}$; this subset is unable to activate the effector functions of naive $\mathrm{T}$ cells but is an efficient inducer of FOXP3 ${ }^{+}$Treg in a cell contact-, IL-18-, and TGF- $\beta$ dependent manner (229). H. pylori-specific Tregs were found to suppress the inflammatory response and reduce gastric ulceration (230). FOXP3 and cAMP were found to upregulate the expression of microRNA miR-155 both in vivo and in vitro, which might represent a new infection-associated carcinogenic mechanism (231). Reductions of Treg frequency had impacts on the tolerance of mice infected as neonates, resulting in significant reductions in bacterial load and development of immune disorders, similar to the pre-neoplastic lesions typically exhibited by adult-infected mice (232).

Regarding commensal microbiota, the role of gut bacteria in regulation of the immune response against gastrointestinal pathogens and the maintenance of homeostasis is currently being assessed (233). Continual exposure to gut bacterial antigens was crucial for the induction of $\mathrm{CD} 4{ }^{+} \mathrm{CD} 62 \mathrm{~L}^{+} \mathrm{GITR}^{+} \mathrm{IL}-10^{+}$ Treg, which exhibited protective behavior in a transfer model of colitis in mice (234). Commensal Clostridium strains were able to induce Treg in mice and humans (235); clusters IV and XIVa colonizing the colon of mouse pTreg through pathways independent of TLRs, NODs, and Dectin-1 (236). Furthermore, metabolites of commensal bacteria might regulate Treg development. For instance, short-chain fatty acids reacquired through 
microbiota reconstitution restored the number of Treg in germ-free (GF) mice (237). Butyrate enhanced acetylation in the FOXP3 locus, resulting in epigenetic regulation of its expression $(233,238)$. Propionate potentiates this phenomenon by mediating the extrathymic differentiation of Treg dependent on CNS1, a specific intronic enhancer (239). However, in the models of GF mice and specific pathogen-free, it is shown that the development and function of Treg occur independently of the presence of the commensal microbiota, probably restricted to the expression of cytokines and costimulatory molecules, which succumbed to discussions about the real role of the microbiota in immunological homeostasis (240).

\section{Fungal Infections}

Continuous contact of immunocompetent hosts with fungal antigens, either as spores spread in the air or through interaction with the microbiota, does not seemingly trigger hypersensitivity reactions or actual fungal infections. This fact denotes the existence of an effective protective immune response and/or regulatory mechanisms that modulate inadequate immune reactions (241). In the latter scenario, Tregs have been suggested as an essential component of antifungal tolerance.

The expression of Treg markers was higher in patients with lobomycosis compared to the control group. This finding lends support to the hypothesis that Tregs play a dominant role in the lesion microenvironment, limiting the polarization of the Th17 response and hindering the development of an effective response $(242,243)$. Similarly, in patients with paracoccidioidomycosis skin lesions, Tregs predominate over other T cell subsets, resulting in control of disease progression. One study emphasized the high frequency of FOXP3 $3^{+}$Treg in lesions with compact granulomas as a possible mechanism for chronicity (244). In mice infected with Paracoccidioides brasiliensis, anti-CD25 treatment caused early Treg depletion, resulting in less severe infection; migration of effector cells to the site of infection was restored, interrupting the progression of infection (245).

A comparison of Candida albicans and Aspergillus fumigatus infections demonstrated an increase in the Treg/Tmem ratio in the latter, which favors immune suppression (246). Epitopes derived from A. fumigatus are able to suppress the expansion of effector $\mathrm{T}$ cells and maintain antifungal immune homeostasis through $\operatorname{Tr} 1$ cell stimulation (247). In vitro stimulation of DCs with A. fumigatus conidia induced expression of Th1- and Tregrelated cytokines but was a weak inducer of Th2/17 responses (248).

Concerningyeast-like fungi, the study of Schulze and colleagues (249) showed that the frequency of Treg in the lungs significantly increased during the first weeks of infection with Cryptococcus neoformans (likely through a TGF- $\beta$-dependent pathway), with suppression of the pathogenic Th2 profile. Joint action of Treg and Th17 cells in antimicrobial immunity was suggested by models of infection with C. albicans, in which Treg promoted differentiation of naive $\mathrm{CD} 4^{+} \mathrm{T}$ cells into Th17 cells independently of the TGF- $\beta$-mediated tolerogenic effect (250). Cereda and colleagues found that cocultured CD4 ${ }^{+} \mathrm{T}$ cells and autologous DCs treated with Saccharomyces cerevisiae (yeast) reduced the Treg rate and favored the development of Th1 effector immune response (251).
To summarize, the available data point to controversies as to the role of Treg in different fungal infections.

\section{Parasitic Diseases}

As immunoregulatory agents, Tregs play a relevant role in the prevention of adverse effects resulting from excessive immune stimulation, which might eventually be fatal (252).

In Chagas disease, a high frequency of FOXP3 ${ }^{+}$Treg was directly correlated with moderate inflammation, thus preventing the development of megacolon (253); a similar association was also found among patients with heart disease (254). While specific suppressor mechanisms are a continuing focus of research, the available data indicate that such cells modulate the cytokine microenvironment, IL-10 and IFN- $\gamma$ in particular, and/or induce lysis of effector cells through a granzyme-dependent pathway in patients with the indeterminate form of Chagas disease (255). In C57BL/6 mice infected with Trypanosoma cruzi, production of endogenous glucocorticoids sustains Treg homeostasis as well as the Treg/effector T cell balance. In addition, treatment combining IL-2 and synthetic steroids induces Treg proliferation and a Th1 imbalance (256). However, discrepant data suggest that Tregs play a limited role in the pathophysiology of experimental infection with T. cruzi, as a slight increase in resistance against the parasite was detected after Treg inactivation in the acute stage of disease (257).

Before treatment for tegumentary leishmaniasis, the expression of Treg markers (e.g., FOXP3 and CTLA-4) and IL-10 levels are elevated in tissue lesions. However, it remains to be established whether Treg accumulation is directly induced by infection or rather represents a local homeostatic mechanism to control excessive inflammation (258). In canine leishmaniasis, Tregs impair the immune response to the point of exacerbating parasite growth. At the same time, Treg recruitment prevents the development of immune-mediated disorders due to the "fine tuning" of regulatory mechanisms critical for the prevention of immune system diseases $(259,260)$.

An adequate immune response contributes to the control of severe malaria. Increased circulation of Treg in the peripheral blood of patients infected with Plasmodium vivax [e.g., through upregulation of S100A8 protein (261)] was associated with parasite load and had a suppressive effect on specific T lymphocytes (262). However, modulation of the effector response hinders the control of parasitemia by enabling uncontrolled parasite growth (263). In other Apicomplexa, such as Toxoplasma gondii, the basal number of Treg during acute infection does not suffice to prevent CD4 ${ }^{+}$ $\mathrm{T}$ cell activation and increased production of pro-inflammatory cytokines. While Treg transfer possibly contributed to increased survival of infected mice, the number of brain cysts was increased, which points to a dual role for Treg in T. gondii infection and the need to maintain a delicate immune balance (264).

The persistence of helminths is also based on the breadth of Treg as a mechanism of resistance against the host immune system (265) (Figure 5). This hypothesis is based on findings showing that the Treg population expands during infection and exposure to antigens excreted or secreted by parasites, leading to changes mainly in the Th2 cell balance (266). Costimulatory molecules, such as inducible T cell costimulator (CD278), participate 
in the activation of FOXP3 ${ }^{+}$Treg and downregulation of pro-Th2 cytokines at both the local and systemic levels (lymph nodes and spleen) in some parasitic infections (267). In a model of Trichuris muris infection, early Treg depletion post-infection was beneficial for hosts; however, the worm burden was enhanced when Tregs were depleted later once infection was established (268).

In schistosomiasis, Tregs regulate the Th2 profile in mesenteric lymph nodes, granulomas, and fibrotic colon responses and reduce eosinophil recruitment (269). However, this might be a parasite stage-specific response, as Schistosoma mansoni larvae do not activate or expand FOXP3 ${ }^{+}$Treg during their early migratory phase (270). Imbalances in the cytokine response favorable to infection with Schistosoma haematobium due to increased frequency of $\mathrm{CD}^{+} \mathrm{CD} 25^{\mathrm{hi}} \mathrm{FOXP} 3^{+}$Treg, among other causes, might be modified by treatment with praziquantel (271).

Infective filarial larvae (L3) recruit tTreg and induce their premature proliferation at the site of infection, rapidly biasing $\mathrm{CD}^{+} \mathrm{T}$ cell responses toward a regulatory phenotype approximately 7 days postinfection. Treatment with anti-CD25 antibodies reduced the fertility rate of parasites and the incidence of infection in experimental animals. CTLA-4, a molecule with the potential to maintain effector cell hyporesponsiveness, is also an attractive therapeutic target for reversion of protective immunity $(272,273)$.

Infection with Trichinella spiralis exhibited anti-inflammatory effects in a model of dextran sulfate sodium-induced colitis through activation of local Treg producing IL-10 and TGF- $\beta$ (274). IL-10 creates an immunoregulatory microenvironment that favors the development of Taenia solium cysticerci and their permanence in the central nervous system. This scenario results from the mutual interaction between Treg and DCs, which induces a tolerogenic phenotype that in turn induces Treg to develop into the $\operatorname{Tr} 1$ phenotype (275). This feedback also occurs in Echinococcus granulosus infection, where the parasite inhibits DC maturation, directing them toward a tolerogenic phenotype; this may drive the differentiation of $\mathrm{CD} 4^{+} \mathrm{T}$ cells into Treg and suppress cytokine production in a generalized manner (276).

\section{FOXP3 MUTATIONS AND THEIR CLINICAL IMPACTS}

\section{Scurfy}

Phenotype sf corresponds to a strain of mice with a recessive mutation on the $\mathrm{X}$ chromosome characterized by a two base pair insertion in exon 8 of the FOXP3 gene, resulting in the loss of the forkhead domain and nuclear localization signal; the encoded protein is truncated and non-functional $(89,277)$.

Hemizygous males $\left(\mathrm{X}^{s f} / \mathrm{Y}\right)$ exhibit fatal autoimmune disorders characterized by lymphoproliferative disease, with progressive infiltration of the lymph nodes, spleen, liver, and skin, causing spleen, liver, and lymph node enlargement, exfoliative dermatitis, leukocytosis, hyperglobulinemia, and severe anemia; precocious death usually occurs by the third to fourth week of life (278-281).

This mutation in the FOXP3 gene causes deficiency of functional Treg, with consequent impact on systemic immune tolerance (282) and resulting in the infiltration of several organs with activated immune cells (283). The sf phenotype is mediated by hyperresponsive helper $\mathrm{T}$ cells via excessive production of a wide range of cytokines (IL-2, IL-4, IL-5, IL-6, IL-10, TNF- $\alpha$, among others) in a generalized manner, which are associated with the typical pathological abnormalities of this phenotype $(284,285)$.

Expression of mutant FOXP3 (sf) in non-hematopoietic cells in the thymus contributes to impaired thymopoiesis, which mainly affects thymocyte stages DN2 and DN4, and to a lesser degree, double-positive immature thymocytes. This, in addition to the remarkable overexpression of the ErbB2 gene in the thymic stroma, suggests a critical role for this gene in thymic atrophy (286).

B lymphocytes and the corresponding autoantibodies worsen the autoimmune effects of hyperglobulinemia and contribute to the early death of mice due to loss of humoral immune tolerance (287). The presence of $\mathrm{T}_{\mathrm{FR}}$, which were suggested to behave as direct modulators of germinal center B cells (288), controls the activation of autoreactive cells indirectly by limiting the number of follicular $\mathrm{T}$ cells in the center, thus limiting the activation of autoantibodies in this microenvironment, although it does not rule out the possibility that $\mathrm{T}_{\mathrm{FR}}$ exert a direct control over the activation of B cells $(287,289)$.

While neonatal thymectomy increases the survival of sf mice and attenuates their immune and clinical state, it cannot prevent the appearance of pathological manifestations derived from the probable generation of fetal T lymphocytes that migrate to other parts of the body, thus supporting the development of the sf phenotype (280). Partial bone marrow transplant and one single infusion of T-enriched splenocytes might rescue the autoimmune sf mouse, which indicates that sf effector $\mathrm{T}$ cells are susceptible to dominant regulation by a small fraction of cells in vivo (290).

\section{Immunodeficiency, Polyendocrinopathy, and Enteropathy $\mathrm{X}$-linked}

A phenotype analogous to murine sf in humans is exhibited by patients with the IPEX syndrome. In this condition, Treg dysfunction causes several fatal autoimmune disorders affecting the intestines, skin, endocrine organs, and blood. Clinically, patients present neonatal insulin-dependent diabetes mellitus, chronic refractory diarrhea, severe food allergies, thrombocytopenia, hemolytic anemia, chronic dermatitis with bullous pemphigoid (in the rarest cases), hyperthyroidism, and lymph node and spleen enlargement (283, 291-297).

A wide variety of autoantibodies are detected in a large portion of IPEX patients; some of them might directly affect target organs, while others might be unrelated to the pathophysiology of disease $(293,298)$. Specific antibodies against autoimmune enteropathy-related antigen (AIE-75) and protein villin-both antigens expressed in the intestinal microvilli and renal proximal tubule - are frequently detected in the serum of IPEX patients and are related to activation of the humoral response and catastrophic local tissue damage (299-301). Specific antibodies against pancreatic islet cells, insulin, or anti-glutamate decarboxylase are 
indicative of neonatal type 1 diabetes; anti-thyroglobulin and anti-microsomal antibodies are related to autoimmune thyroiditis (302). Anti-mitochondrial antibodies are typically associated with primary liver cirrhosis in adults (298).

The first study that linked the IPEX syndrome with genetic variations in FOXP3 was devised by Bennett et al., in which the authors identified distinct mutant profiles in the gene in two affected families (303). Currently, about 63 mutations in the FOXP3 gene related to the etiology of IPEX have already been reported (303), mainly affecting the forkhead domain, the LeuZip domain, and the protein N-terminal portion (21). Mutations in the polyadenylation site lead to unstable FOXP3 expression, which is associated with early worsening of disease (304). Similar complications occur in carriers of missense mutations due to abnormalities in the expression of the mutant protein (305).

Treatment options for IPEX are limited and are based on individual cases. General measures include blood transfusion, insulin replacement therapy, antibiotic prophylaxis, and immunosuppressive agents, which mostly only afford transient relief $(296,305)$. However, a recent study by Chen and colleagues found that rituximab monotherapy or combined with tacrolimus was effective in inducing suppression of Th2 cells, which mediate gastrointestinal and kidney lesions in the IPEX (306). Functional cure is achieved through hematopoietic stem cell transplantation, especially when performed in the first years of life (307); both myeloablative and non-myeloablative conditioning regimens are used to avoid complications associated with transplantation (302).

\section{Genetic Polymorphisms}

In addition to the aforementioned classic mutations, the immunological relevance of polymorphisms in various regions of the FOXP3 gene is being investigated.

As the promoter region is involved in initiating transcription as well as in the interaction with cis-acting elements that regulate gene expression, it was suggested that this region might harbor functionally relevant polymorphisms. Such polymorphisms might eventually reflect on the FOXP3 expression level and consequently on Treg activation, as in the case of autoimmune diseases (308). Five single-nucleotide polymorphisms (SNP) have been described in the FOXP3 promoter region: -924A/G (rs2232365), -1383C/T (rs2232364), -2383C/T (rs3761549), -3279C/A (rs3761548), and -3499A/G (rs3761547) $(309,310)$.

Binding site analysis of the -924A/G (rs2232365) SNP showed that it interacts with the transcription factor GATA-3, which plays an essential role in Th2 responses; the presence of the mutant $\mathrm{G}$ allele was suggested to interfere with this interaction. The -924A/G (rs2232365) SNP was significantly associated with the occurrence of spontaneous abortion in a Chinese Han population (311), psoriasis (312), and chronic rhinosinusitis (313); this association was not confirmed for Crohn's disease (314) or Graves' disease (26). Mutant haplotype carriers of rs2232365, rs3761548, rs5902434, and rs2294021 SNPs exhibited 2.5 times higher risks of recurrent idiopathic abortion (315). Combined analysis of variants rs2232365 and rs3761548 showed that carriers of mutant alleles in specific subgroups of the Han people exhibited higher risk of vitiligo (316).
Functional differences in the -2383C/T (rs3761549) SNP were first suggested in the study of Inoue and colleagues, who found low FOXP3 expression levels and decreased Treg suppressor function in genotype CC carriers. This reduction in regulatory function might increase the activity of autoreactive $\mathrm{T}$ cells accompanied by severe destruction of the thyroid tissue in patients with Hashimoto's disease (317). The $-2383 \mathrm{C} / \mathrm{T}$ (rs3761549) SNP, in association with the FCRL3 gene (318), was also related to the occurrence of endometriosis, independently of the stage of disease (319), with a predisposition to Graves' disease (320) and food allergy development (321); the T allele was rated as a risk factor for SLE in a Chinese population (322). The -3499A/G (rs3761547) SNP was also studied by Inoue and colleagues in relation to the prognosis of Hashimoto's and Graves' disease, but no significant differences in the genotypic or allelic frequencies of this polymorphism were detected (317), similar to the case of juvenile idiopathic arthritis (323).

Shen and colleagues suggested that carriers of the AA genotype of SNP -3279C/A (rs3761548) have abrogated binding to the E47 and c-Myb transcription factors, which results in defective transcription of FOXP3 (324). A considerable number of published studies have associated this polymorphism with diseases and other conditions that reflect Treg deficiency, such as allergic rhinitis (325), susceptibility to vitiligo (326), psoriasis (327), some autoimmune diseases (328), non-small-cell lung cancer (329), and breast cancer (330). This association has not been confirmed for other disorders, including endometriosis-associated infertility (319) and systemic sclerosis (331).

Microsatellite polymorphisms $\left(\mathrm{GT}_{\mathrm{n}}\right)$ in the FOXP3 promoter region were also investigated. Ban and colleagues found an association between this type of polymorphism and thyroid autoimmune diseases in a European, but not Japanese, cohort (332). Another study found a positive relationship between this polymorphism and survival in kidney transplant recipients (333). However, the presence of $\mathrm{GT}_{\mathrm{n}}$ was considered irrelevant for susceptibility to SLE, rheumatoid arthritis, inflammatory bowel disease, and celiac disease (334).

Some SNPs have been described in the FOXP3 intronic region, such as $-20 \mathrm{~A} / \mathrm{G}$ (rs2232368), +87G/T (rs2232366), +459C/T (rs2280883), +459C/T (IVS9), among others (310). Analysis of the rs2232368 and rs2280883 polymorphisms revealed a possible association with idiopathic infertility; a similar relationship was not found for the rs2232366 polymorphism (319). The rs2280883 variant was associated with susceptibility to systemic sclerosis in Italian patients (331), and its genotypic frequency exhibited significant differences in patients with primary biliary cirrhosis (335). The mutant TT genotype was found to be more frequent among patients with hepatitis B-related hepatocellular carcinoma (336).

The +459 C/T (IVS9) SNP was associated with a risk of myasthenia gravis in a Han Chinese population, with wild allele $\mathrm{C}$ being a protective factor against this condition (337). In turn, genotype CC was associated with a risk of severe psoriasis also in a Han Chinese population (327), and this effect was age-dependent; associations of this polymorphism with lung cancer were found among aged patients (338). 
Four further intronic polymorphisms were studied by Bottema and colleagues: variants rs5906761 (upstream of exon 1) and rs2294021, rs2294019, and rs6609857 (located at the 3 '-end). These authors found an association between the investigated SNPs and allergic sensitization to egg among girls aged 1-2 years old. In turn, polymorphisms rs5906761 and rs2294021 were associated with remission of sensitization to food allergens in boys (321).

Few studies have investigated the association between exonic variants and modulation of FOXP3 expression. Kim and colleagues analyzed the coding regions of exons $2-12$ in acute leukemia patients but failed to detect any mutations. According to these authors, mutations in FOXP3 occur exclusively in some types of tumors, such as breast and prostate cancer (339). The study of Bafunno and colleagues did not find any association between polymorphisms in exon 12 and the formation of neutralizing antibodies in hemophilia A (340).

\section{CONCLUSION}

Mechanisms that regulate the immune response are essential in maintaining the homeostatic balance between the immune activation necessary to give combat to a specific manifestation and the control of possible damages generated by the exacerbated expression of this response. The present review brings together a number of relevant studies on the role that Treg and FOXP3 play as modulating mechanisms in the immunological response. It is argued that these factors actively participate in the immunoregulation of both pathological conditions and in more specific

\section{REFERENCES}

1. Kurt-Jones EA, Chan M, Zhou S, Wang J, Reed G, Bronson R, et al. Herpes simplex virus 1 interaction with Toll-like receptor 2 contributes to lethal encephalitis. Proc Natl Acad Sci U S A (2004) 101(5):1315-20. doi:10.1073/ pnas.0308057100

2. Amura CR, Renner B, Lyubchenko T, Faubel S, Simonian PL, Thurman JM. Complement activation and toll-like receptor-2 signaling contribute to cytokine production after renal ischemia/reperfusion. Mol Immunol (2012) 52(3-4):249-57. doi:10.1016/j.molimm.2012.05.020

3. Pandey S, Singh S, Anang V, Bhatt AN, Natarajan K, Dwarakanath BS. Pattern recognition receptors in cancer progression and metastasis. Cancer Growth Metastasis (2015) 8:25-34. doi:10.4137/CGM.S24314

4. Surbatovic M, Jevdjic J, Veljovic M, Popovic N, Djordjevic D, Radakovic S. Immune response in severe infection: could life-saving drugs be potentially harmful? ScientificWorldJournal (2013) 2013:961852. doi:10.1155/2013/ 961852

5. Ribas A. Adaptive immune resistance: how cancer protects from immune attack. Cancer Discov (2015) 5(9):915-9. doi:10.1158/2159-8290.CD15-0563

6. Guerder S, Picarella DE, Linsley PS, Flavell RA. Costimulator B7-1 confers antigen-presenting-cell function to parenchymal tissue and in conjunction with tumor necrosis factor alpha leads to autoimmunity in transgenic mice. Proc Natl Acad Sci U S A (1994) 91(11):5138-42. doi:10.1073/pnas.91.11.5138

7. Legoux FP, Lim JB, Cauley AW, Dikiy S, Ertelt J, Mariani TJ, et al. CD4+ T cell tolerance to tissue-restricted self antigens is mediated by antigen-specific regulatory $\mathrm{T}$ cells rather than deletion. Immunity (2015) 43(5):896-908. doi:10.1016/j.immuni.2015.10.011

8. Billerbeck E, Böttler T, Thimme R. Regulatory T cells in viral hepatitis. World J Gastroenterol (2007) 13(36):4858-64. doi:10.3748/wjg.v13.i36.4858

9. Bluestone JA, Abbas AK. Natural versus adaptive regulatory T cells. Nat Rev Immunol (2003) 3:253-7. doi:10.1038/nri1032 immunotolerance contexts. Thus, the discrepancies related to the functional benefits of these factors are dependent on the context discussed, since immunoregulation may favor immunotolerance and decrease the tissue aggression generated by the immune response. It is relevant to mention that it provides mechanisms of immune escape to infectious agents or microenvironments permissible to the carcinogenic activity. Efforts are being made to understand new therapeutic platforms involving the potential suppressor of Treg in stimulus models and by direct transfer of these cells, in addition to studies that investigate whether genetic variations in the FOXP3 gene may be risk factors for the involvement of other pathologies.

\section{AUTHOR CONTRIBUTIONS}

LP, SG, RI, and AV contributed equally to the design and writing of the present review.

\section{ACKNOWLEDGMENTS}

We thank Universidade Federal do Pará for supporting the English review. LP is supported by grants from the Conselho Nacional de Ciência e Tecnologia (CNPq). AV and RI are supported by a grant from the CNPq.

\section{FUNDING}

The present work was supported by grants (No. 48128/2013-8) from the Conselho Nacional de Ciência e Tecnologia (CNPq).

10. Ding $\mathrm{Y}, \mathrm{Xu}$ J, Bromberg JS. Regulatory $\mathrm{T}$ cell migration during an immune response. Trends Immunol (2012) 33(4):174-80. doi:10.1016/j.it.2012.01.002

11. Chattopadhyay S, Chakraborty NG, Mukherji B. Regulatory T cells and tumor immunity. Cancer Immunol Immunother (2005) 54(912):1153-61. doi:10.1007/s00262-005-0699-9

12. Haas J, Hug A, Viehöver A, Fritzsching B, Falk CS, Filser A, et al. Reduced suppressive effect of $\mathrm{CD} 4+\mathrm{CD} 25$ high regulatory $\mathrm{T}$ cells on the $\mathrm{T}$ cell immune response against myelin oligodendrocyte glycoprotein in patients with multiple sclerosis. Eur J Immunol (2005) 35(11):3343-52. doi:10.1002/ eji.200526065

13. Fontenot JD, Gavin MA, Rudensky AY. Foxp3 programs the development and function of CD4+CD25+ regulatory T cells. Nat Immunol (2003) 4:330-6. doi:10.1038/ni904

14. Chen W, Jin W, Hardegen N, Lei KJ, Li L, Marinos N, et al. Conversion of peripheral $\mathrm{CD} 4+\mathrm{CD} 25^{-}$naive $\mathrm{T}$ cells to $\mathrm{CD} 4+\mathrm{CD} 25+$ regulatory $\mathrm{T}$ cells by TGF-beta induction of transcription factor Foxp3. J Exp Med (2003) 198:1875-86. doi:10.1084/jem.20030152

15. Al-Wedaie F, Farid E, Tabbara K, El-Agroudy AE, Al-Ghareeb SM. T-regulatory cells in chronic rejection versus stable grafts. Exp Clin Transplant (2015) 13:170-6.

16. Sewgobind VDKD, Van Der Laan LJW, Klepper M, Ijzermans JNM, Tilanus HW, Weimar W, et al. Functional analysis of $\mathrm{CD} 4{ }^{+} \mathrm{CD} 25^{\text {bright }}$ $\mathrm{T}$ cells in kidney transplant patients: improving suppression of donor-directed responses after transplantation. Clin Transplant (2008) 22:579-86. doi:10.1111/j.1399-0012.2008.00827.x

17. Lee ES, Lim JY, Im KI, Kim N, Nam YS, Jeon YW, et al. Adoptive transfer of Treg cells combined with mesenchymal stem cells facilitates repopulation of endogenous treg cells in a murine acute GVHD model. PLoS One (2015) 10(9):e0138846. doi:10.1371/journal.pone.0138846

18. Stroud JC, Wu Y, Bates DL, Han A, Nowick K, Paabo S, et al. Structure of the forkhead domain of FOXP2 bound to DNA. Structure (2006) 14(1):159-66. doi:10.1016/j.str.2005.10.005 
19. Kaufmann E, Knöchel W. Five years on the wings of fork head. Mech Dev (1996) 57:3-20. doi:10.1016/0925-4773(96)00539-4

20. Kaestner KH, Knochel W, Martinez DE. Unified nomenclature for the winged helix/forkhead transcription factors. Genes Dev (2000) 14:142-6.

21. Lopes JE, Torgerson TR, Schubert LA, Anover SD, Ocheltree EL, Ochs HD, et al. Analysis of FOXP3 reveals multiple domains required for its function as a transcriptional repressor. J Immunol (2006) 177:3133-42. doi:10.4049/ jimmunol.177.5.3133

22. McCarty AS, Kleiger G, Eisenberg D, Smale ST. Selective dimerization of a C2H2 zinc finger subfamily. Mol Cell (2003) 11:459-70. doi:10.1016/ S1097-2765(03)00043-1

23. Wu Y, Borde M, Heissmeyer V, Feuerer M, Lapan AD, Stroud JC, et al. FOXP3 controls regulatory $\mathrm{T}$ cell function through cooperation with NFAT. Cell (2006) 126:375-87. doi:10.1016/j.cell.2006.05.042

24. Gambineri E, Torgerson TR, Ochs HD. Immune dysregulation, polyendocrinopathy, enteropathy, and X-linked inheritance (IPEX), a syndrome of systemic autoimmunity caused by mutations of FOXP3, a critical regulator of T-cell homeostasis. Curr Opin Rheumatol (2003) 15:430-5. doi:10.1097/00002281-200307000-00010

25. Li B, Greene MI. FOXP3 actively represses transcription by recruiting the HAT/HDAC complex. Cell Cycle (2007) 6:1432-6. doi:10.4161/cc.6. 12.4421

26. Owen CJ, Eden JA, Jennings CE, Wilson V, Cheetham TD, Pearce SH. Genetic association studies of the FOXP3 gene in Graves' disease and autoimmune Addison's disease in the United Kingdom population. J Mol Endocrinol (2006) 37:97-104. doi:10.1677/jme.1.02072

27. Walker MR, Kasprowicz DJ, Gersuk VH, Benard A, Van Landeghen M, Buckner JH, et al. Induction of FOXP3 and acquisition of T regulatory activity by stimulated human $\mathrm{CD}^{+} \mathrm{CD} 25^{-} \mathrm{T}$ cells. J Clin Invest (2003) 112:1437-43. doi:10.1172/JCI19441

28. Allan SE, Passerini L, Bacchetta R, Crellin N, Dai M, Orban PC, et al. The role ofFOXP3, and an isoform lacking exon 2, in the generation of human $\mathrm{CD} 4^{+}$ T regulatory cells. J Clin Invest (2005) 115:3276-84. doi:10.1172/JCI24685

29. Du J, Huang C, Zhou B, Ziegler SF. Isoform-specific inhibition of RORmediated transcriptional activation by human FOXP3. JImmunol (2008) 180:4785-92. doi:10.4049/jimmunol.180.7.4785

30. Smith EL, Finney HM, Nesbitt AM, Ramsdell F, Robinson MK. Splice variants of human FOXP3 are functional inhibitors of human $\mathrm{CD} 44^{+} \mathrm{T}$-cell activation. Immunology (2006) 119:203-11. doi:10.1111/j.1365-2567.2006.02425.x

31. Hori S, Nomura T, Sakaguchi S. Control of regulatory T cell development by the transcription factor FOXP3. Science (2003) 299:1057-61. doi:10.1126/ science. 1079490

32. Gottschalk RA, Corse E, Allison JP. TCR ligand density and affinity determine peripheral induction of Foxp3 in vivo. J Exp Med (2010) 207(8):1701-11. doi:10.1084/jem.20091999

33. Li C, Ebert PJ, Li QJ. T cell receptor (TCR) and transforming growth factor $\beta$ (TGF- $\beta$ ) signaling converge on DNA (cytosine-5)-methyltransferase to control forkhead box protein 3 (foxp3) locus methylation and inducible regulatory T cell differentiation. J Biol Chem (2013) 288(26):19127-39. doi:10.1074/jbc.M113.453357

34. Weissler KA, Garcia V, Kropf E, Aitken M, Bedoya F, Wolf AI, et al. Distinct modes of antigen presentation promote the formation, differentiation, and activity of FOXP3 ${ }^{+}$regulatory T cells in vivo. J Immunol (2015) 194:3784-97. doi:10.4049/jimmunol.1402960

35. Vaeth M, Schliesser U, Müller G, Reissig S, Satoh K, Tuettenberg A, et al. Dependence on nuclear factor of activated T-cells (NFAT) levels discriminates conventional T cells from Foxp3+ regulatory T cells. Proc Natl Acad Sci U S A (2012) 109:16258-63. doi:10.1073/pnas.1203870109

36. Bettelli E, Dastrange M, Oukka M. FOXP3 interacts with nuclear factor of activated $\mathrm{T}$ cells and NF-kB to repress cytokine gene expression and effector functions of T helper cells. Proc Natl Acad Sci U S A (2005) 102:5138-43. doi:10.1073/pnas.0501675102

37. Hori S, Sakaguchi S. FOXP3: a critical regulator of the development and function of regulatory T cells. Microbes Infect (2004) 6:745-51. doi:10.1016/j. micinf.2004.02.020

38. Li B, Samanta A, Song X, Iacono KT, Bembas K, Tao R, et al. FOXP3 interactions with histone acetyltransferase and class II histone deacetylases are required for repression. Proc Natl Acad Sci U S A (2007) 104(11):4571-6. doi:10.1073/pnas.0700298104
39. Rudra D, deRoos P, Chaudhry A, Niec RE, Arvey A, Samstein RM, et al. Transcription factor Foxp3 and its protein partners form a complex regulatory network. Nat Immunol (2012) 13(10):1010-9. doi:10.1038/ni.2402

40. Li B, Samanta A, Song X, Iacono KT, Brennan P, Chatila TA, et al. FOXP3 is a homo-oligomer and a component of a supramolecular regulatory complex disabled in the human XLAAD/IPEX autoimmune disease. Int Immunol (2007) 19(7):825-35. doi:10.1093/intimm/dxm043

41. Lal G, Bromberg JS. Epigenetic mechanisms of regulation of FOXP3 expression. Blood (2009) 114:3727-35. doi:10.1182/blood-2009-05-219584

42. Zheng SG, Wang JH, Gray JD, Soucier H, Horwitz DA. Natural and induced $\mathrm{CD} 4^{+} \mathrm{CD} 25^{+}$cells educate $\mathrm{CD} 4^{+} \mathrm{CD} 25^{-}$cells to develop suppressive activity: the role of IL-2, TGF- $\beta$, and IL-10. J Immunol (2004) 172:5213-21.

43. Pyzik M, Piccirillo CA. TGF- $\beta 1$ modulates FOXP3 expression and regulatory activity in distinct CD4 ${ }^{+} \mathrm{T}$ cell subsets. JLeukoc Biol (2007) 82:335-46. doi:10.1189/jlb.1006644

44. Pierson W, Cauwe B, Policheni A, Schlenner SM, Franckaert D, Berges J, et al. Antiapoptotic Mcl- 1 is critical for the survival and niche-filling capacity of FOXP $3^{+}$regulatory T cells. Nat Immunol (2013) 14:959-65. doi:10.1038/ ni. 2649

45. Nie H, Zheng Y, Li R, Guo TB, He D, Fang L, et al. Phosphorylation of FOXP3 controls regulatory T cell function and is inhibited by TNF- $\alpha$ in rheumatoid arthritis. Nat Med (2013) 19:322-8. doi:10.1038/nm.3085

46. Hoeppli RE, Wu D, Cook L, Levings MK. The environment of regulatory $\mathrm{T}$ cell biology: cytokines, metabolites, and the microbiome. Front Immunol (2015) 6:61. doi:10.3389/fimmu.2015.00061

47. Bacchetta R, Gambineri E, Roncarolo M-G. Role of regulatory T cells and FOXP3 in human diseases. JAllergy Clin Immunol (2007) 120:227-35. doi:10.1016/j.jaci.2007.06.023

48. Stephens LA, Mason D. CD25 is a marker for $\mathrm{CD} 4^{+}$thymocytes that prevent autoimmune diabetes in rats, but peripheral $\mathrm{T}$ cells with this function are found in both $\mathrm{CD} 25^{+}$and CD25- subpopulations. J Immunol (2000) 165:3105-10. doi:10.4049/jimmunol.165.6.3105

49. Apostolou I, Sarukhan A, Klein L, von Boehmer H. Origin of regulatory T cells with known specificity for antigen. Nat Immunol (2002) 3:756-63.

50. Salomon B, Lenschow DJ, Rhee L, Ashourian N, Singh B, Sharpe A, et al. B7/CD28 costimulation is essential for the homeostasis of the $\mathrm{CD} 4{ }^{+} \mathrm{CD} 25^{+}$immunoregulatory $\mathrm{T}$ cells that control autoimmune diabetes. Immunity (2000) 12:431-40. doi:10.1016/S1074-7613(00)80195-8

51. Fontenot JD, Rasmussen JP, Williams LM, Dooley JL, Farr AG, Rudensky AY. Regulatory $\mathrm{T}$ cell lineage specification by the forkhead transcription factor FOXP3. Immunity (2005) 22:329-41. doi:10.1016/j.immuni.2005.01.016

52. Ngoma AM, Ikeda K, Hashimoto Y, Mochizuki K, Takahashi H, Sano H, et al. Impaired regulatory $\mathrm{T}$ cell reconstitution in patients with acute graftversus-host disease and cytomegalovirus infection after allogeneic bone marrow transplantation. Int J Hematol (2012) 95(1):86-9. doi:10.1007/ s12185-011-0976-7

53. Smyth LJ, Eustace A, Kolsum U, Blaikely J, Singh D. Increased airway T regulatory cells in asthmatic subjects. Chest (2010) 138(4):905-12. doi:10.1378/ chest.09-3079

54. Moradi B, Schnatzer P, Hagmann S, Rosshirt N, Gotterbarm T, Kretzer JP. $\mathrm{CD} 4^{+} \mathrm{CD} 25^{+} /$highCD 127 low $^{--}$regulatory T cells are enriched in rheumatoid arthritis and osteoarthritis joints - analysis of frequency and phenotype in synovial membrane, synovial fluid and peripheral blood. Arthritis Res Ther (2014) 16(2):R97. doi:10.1186/ar4545

55. Caramalho I, Lopes-Carvalho T, Ostler D, Zelenay S, Haury M, Demengeot J. Regulatory T cells selectively express Toll-like receptors and are activated by lipopolysaccharide. J Exp Med (2003) 197:403-11. doi:10.1084/jem.20021633

56. Baecher-Allan C, Viglietta V, Hafler DA. Human $\mathrm{CD} 4{ }^{+} \mathrm{CD} 25^{+}$regulatory T cells. Semin Immunol (2004) 16:89-98. doi:10.1016/j.smim.2003.12.005

57. Seddiki N, Santner-Nanan B, Martinson J, Zaunders J, Sasson S, Landay A, et al. Expression of interleukin (IL)-2 and IL-7 receptors discriminates between human regulatory and activated T cells. J Exp Med (2006) 203:1693700. doi:10.1084/jem.20060468

58. Wakkach A, Fournier N, Brun V, Breittmayer J-P, Cottrez F, Groux H. Characterization of dendritic cells that induce tolerance and $\mathrm{T}$ regulatory 1 cell differentiation in vivo. Immunity (2003) 18:605-17. doi:10.1016/ S1074-7613(03)00113-4

59. Strober S, Cheng L, Zeng D, Palathumpat R, Dejbakhsh-Jones S, Huie P, et al. Double negative (CD4-CD8-alphabeta+) T cells which promote tolerance 
induction and regulate autoimmunity. Immunol Rev (1996) 149:217-30. doi:10.1111/j.1600-065X.1996.tb00906.x

60. Levings MK, Sangregorio R, Galbiati F, Squadrone S, de Waal Malefyt R, Roncarolo MG. IFN- $\alpha$ and IL-10 induce the differentiation of human type 1 T regulatory cells. J Immunol (2001) 166:5530-9. doi:10.4049/ jimmunol.166.9.5530

61. Fujio K, Okamura T, Yamamoto K. The family of IL-10-secreting $\mathrm{CD} 4^{+} \mathrm{T}$ cells. Adv Immunol (2010) 105:99-130. doi:10.1016/S0065-2776(10)05004-2

62. Wan YY, Flavell RA. 'Yin-Yang' functions of transforming growth factor- $\beta$ and $T$ regulatory cells in immune regulation. Immunol Rev (2007) 220:199-213. doi:10.1111/j.1600-065X.2007.00565.x

63. Zeng D, Lewis D, Dejbakhsh-Jones S, Lan F, García-Ojeda M, Sibley R, et al. Bone marrow NK1.1(-) and NK1.1(+) T cells reciprocally regulate acute graft versus host disease. J Exp Med (1999) 189:1073-81. doi:10.1084/ jem.189.7.1073

64. Xystrakis E, Dejean AS, Bernard I, Druet P, Liblau R, Gonzalez-Dunia D, et al. Identification of a novel natural regulatory CD8 T-cell subset and analysis of its mechanism of regulation. Blood (2004) 104:3294-301. doi:10.1182/ blood-2004-03-1214

65. Ke Y, Pearce K, Lake JP, Ziegler HK, Kapp JA. Gamma delta T lymphocytes regulate the induction and maintenance of oral tolerance. J Immunol (1997) 158:3610-8.

66. Sojka DK, Huang Y-H, Fowell DJ. Mechanisms of regulatory T-cell suppression-a diverse arsenal for a moving target. Immunology (2008) 124:13-22. doi:10.1111/j.1365-2567.2008.02813.x

67. Magnani CF, Alberigo G, Bacchetta R, Serafini G, Andreani M, Roncarolo MG, et al. Killing of myeloid APCs via HLA class I, CD2 and CD226 defines a novel mechanism of suppression by human Tr1 cells. Eur J Immunol (2011) 41:1652-62. doi:10.1002/eji.201041120

68. Fallarino F, Grohmann U, Hwang KW, Orabona C, Vacca C, Bianchi R, et al. Modulation of tryptophan catabolism by regulatory T cells. Nat Immunol (2003) 4:1206-12. doi:10.1038/ni1003

69. Takahashi T, Tagami T, Yamazaki S, Uede T, Shimizu J, Sakaguchi N, et al. Immunologic self-tolerance maintained by $\mathrm{CD} 25^{+} \mathrm{CD} 4^{+}$regulatory $\mathrm{T}$ cells constitutively expressing cytotoxic $\mathrm{T}$ lymphocyte-associated antigen 4 . J Exp Med (2000) 192:303-10. doi:10.1084/jem.192.2.303

70. Liang B, Workman C, Lee J, Chew C, Dale BM, Colonna L, et al. Regulatory $\mathrm{T}$ cells inhibit dendritic cells by lymphocyte activation gene-3 engagement of MHC class II. J Immunol (2008) 180:5916-26. doi:10.4049/ jimmunol.180.9.5916

71. Huang C-T, Workman CJ, Flies D, Pan X, Marson AL, Zhou G, et al. Role of LAG-3 in regulatory T cells. Immunity (2004) 21:503-13. doi:10.1016/j. immuni.2004.08.010

72. Bopp T, Becker C, Klein M, Klein-Heßling S, Palmetshofer A, Serfling E, et al. Cyclic adenosine monophosphateis a key component of regulatory T cell-mediated suppression. J Exp Med (2007) 204:1303-10. doi:10.1084/ jem.20062129

73. Deaglio S, Dwyer KM, Gao W, Friedman D, Usheva A, Erat A, et al. Adenosine generation catalyzedby $\mathrm{CD} 39$ and $\mathrm{CD} 73$ expressed on regulatory $\mathrm{T}$ cells mediatesimmune suppression. J Exp Med (2007) 204:1257-65. doi:10.1084/ jem. 20062512

74. Hershfield MS. New insights into adenosine-receptor-mediated immunosuppression and the role of adenosine in causing the immunodeficiency associated with adenosine deaminase deficiency. Eur J Immunol (2005) 35:25-30. doi:10.1002/eji.200425738

75. Minguet S, Huber M, Rosenkranz L, Schamel WWA, Reth M, Brummer T. Adenosine and CAMP are potent inhibitors of the NF-kappaB pathway downstream of immunoreceptors. Eur J Immunol (2005) 35:31-41. doi:10.1002/ eji.200425524

76. Gorelik L, Flavell RA. Abrogation of TGF $\beta$ signaling in T cells leads to spontaneous T cell differentiation and autoimmune disease. Immunity (2000) 12:171-81. doi:10.1016/S1074-7613(00)80170-3

77. Gorham JD, Guler ML, Fenoglio D, Gubler U, Murphy KM. Low dose TGF- $\beta$ attenuates IL-12 responsiveness in murine Th cells. J Immunol (1998) $161: 1664-70$

78. Kuwahara M, Yamashita M, Shinoda K, Tofukuji S, Onodera A, Shinnakasu $\mathrm{R}$, et al. The transcription factor Sox 4 is a downstream target of signaling by the cytokine TGF- $\beta$ and suppresses T(H)2 differentiation. Nat Immunol (2012) 13:778-86. doi:10.1038/ni.2362
79. Gregori S, Goudy KS, Roncarolo MG. The cellular and molecular mechanisms of immuno-suppression by human type 1 regulatory T cells. Front Immunol (2012) 3:30. doi:10.3389/fimmu.2012.00030

80. Meiler F, Zumkehr J, Klunker S, Rückert B, Akdis CA, Akdis M. In Vivoswitch to IL-10-secreting $\mathrm{T}$ regulatory cells in high dose allergen exposure. J Exp Med (2008) 205:2887-98. doi:10.1084/jem.20080193

81. Pandiyan P, Zheng L, Ishihara S, Reed J, Lenardo MJ. CD $4^{+} \mathrm{CD} 25^{+} \mathrm{FOXP} 3^{+}$ regulatory $\mathrm{T}$ cells induce cytokine deprivation-mediated apoptosis of effector $\mathrm{CD}^{+}$T cells. Nat Immunol (2007) 8:1353-62. doi:10.1038/ni1536

82. Thornton AM, Shevach EM. $\mathrm{CD} 4^{+} \mathrm{CD} 25^{+}$immunoregulatory $\mathrm{T}$ cells suppress polyclonal $\mathrm{T}$ cell activation in vitro by inhibiting interleukin 2 production. J Exp Med (1998) 188:287-96. doi:10.1084/jem.188.2.287

83. Liu Z, Gerner MY, Van Panhuys N, Levine AG, Rudensky AY, Germain RN. Immune homeostasis enforced by co-localized effector and regulatory T cells. Nature (2015) 528:225-30. doi:10.1038/nature 16169

84. Nishizuka Y, Sakakura T. Thymus and reproduction: sex-linked dysgenesia of the gonad after neonatal thymectomy in mice. Science (1969) 166:753-5. doi:10.1126/science. 166.3906 .753

85. Penhale WJ, Farmer A, McKenna RP, Irvine WJ. Spontaneous thyroiditis in thymectomized and irradiated Wistar rats. Clin Exp Immunol (1973) 15:225-36.

86. Asano M, Toda M, Sakaguchi N, Sakaguchi S. Autoimmune disease as a consequence of developmental abnormality of a T cell subpopulation. J Exp Med (1996) 184:387-96. doi:10.1084/jem.184.2.387

87. Young NA, Sharma R, Friedman AK, Kaffenberger BH, Bolon B, Jarjour $\mathrm{WN}$. Aberrant muscle antigen exposure in mice is sufficient to cause myositis in a Treg cell-deficient milieu. Arthritis Rheum (2013) 65(12):3259-70. doi:10.1002/art.38184

88. Lapierre P, Béland K, Martin C, Alvarez F Jr, Alvarez F. Forkhead box p3+ regulatory $\mathrm{T}$ cell underlies male resistance to experimental type 2 autoimmune hepatitis. Hepatology (2010) 51(5):1789-98. doi:10.1002/hep.23536

89. Brunkow ME, Jeffery EW, Hjerrild KA, Paeper B, Clark LB, Yasayko SA, et al. Disruption of a new forkhead/winged-helix protein, scurfin, results in the fatal lymphoproliferative disorder of the scurfy mouse. Nat Genet (2001) 27:68-73. doi:10.1038/83784

90. Sakaguchi S. The origin of FOXP3-expressing CD4+ regulatory T cells: thymus or periphery. J Clin Invest (2003) 112:1310-2. doi:10.1172/JCI200320274

91. Miller DC, Whittington KB, Brand DD, Hasty KA, Rosloniec EF. The CIIspecific autoimmune T-cell response develops in the presence of FTY720 but is regulated by enhanced Treg cells that inhibit the development of autoimmune arthritis. Arthritis Res Ther (2016) 18:8. doi:10.1186/s13075-015-0909-6

92. Astry B, Venkatesha SH, Moudgil KD. Involvement of the IL-23/IL-17 axis and the Th17/Treg balance in the pathogenesis and control of autoimmune arthritis. Cytokine (2015) 74(1):54-61. doi:10.1016/j.cyto.2014.11.020

93. Erhardt A, Biburger M, Papadopoulos T, Tiegs G. IL-10, regulatory T cells, and Kupffer cells mediate tolerance in concanavalin A-induced liver injury in mice. Hepatology (2007) 45:475-85. doi:10.1002/hep.21498

94. Wei HX, Chuang YH, Li B, Wei H, Sun R, Moritoki Y, et al. $\mathrm{CD} 4^{+} \mathrm{CD} 25^{+}$ Foxp $3^{+}$regulatory $\mathrm{T}$ cells protect against $\mathrm{T}$ cell-mediated fulminant hepatitis in a TGF- $\beta$-dependent manner in mice. J Immunol (2008) 181:7221-9. doi:10.4049/jimmunol.181.10.7221

95. Harrison OJ, Powrie FM. Regulatory T cells and immune tolerance in the intestine. Cold Spring Harb Perspect Biol (2013) 5:a018341. doi:10.1101/ cshperspect.a018341

96. Schiering C, Krausgruber T, Chomka A, Fröhlich A, Adelmann K, Wohlfert $\mathrm{EA}$, et al. The alarmin IL-33 promotes regulatory T-cell function in the intestine. Nature (2014) 513(7519):564-8. doi:10.1038/nature13577

97. Bapat SP, Myoung Suh J, Fang S, Liu S, Zhang Y, Cheng A, et al. Depletion of fat-resident Treg cells prevents age-associated insulin resistance. Nature (2015) 528(7580):137-41. doi:10.1038/nature16151

98. Maloy KJ, Salaun L, Cahill R, Dougan G, Saunders NJ, Powrie F. CD $4^{+} \mathrm{CD} 25^{+}$ $\mathrm{T}(\mathrm{R})$ cells suppress innate immune pathology through cytokine-dependent mechanisms. J Exp Med (2003) 197:111-9. doi:10.1084/jem.20021345

99. Dudda JC, Perdue N, Bachtanian E, Campbell DJ. FOXP3 $3^{+}$regulatory T cells maintain immune homeostasis in the skin. J Exp Med (2008) 205:1559-65. doi:10.1084/jem.20072594

100. Rosenblum MD, Gratz IK, Paw JS, Lee K, Marshak-Rothstein A, Abbas AK. Response to self antigen imprints regulatory memory in tissues. Nature (2012) 480:538-42. doi:10.1038/nature10664 
101. Sanchez Rodriguez R, Pauli ML, Neuhaus IM, Yu SS, Arron ST, Harris HW, et al. Memory regulatory T cells reside in human skin. J Clin Invest (2014) 124:1027-36. doi:10.1172/JCI72932

102. Gratz IK, Truong HA, Yang SHY, Maurano MM, Lee K, Abbas AK, et al. Cutting edge: memory regulatory $\mathrm{T}$ cells require IL-7 and not IL-2 for their maintenance in peripheral tissues. JImmunol (2013) 190:4483-7. doi:10.4049/jimmunol.1300212

103. Bakdash G, Vogelpoel LT, Van Capel TM, Kapsenberg ML, de Jong EC. Retinoic acid primes human dendritic cells to induce gut-homing, IL-10producing regulatory T cells. Mucosal Immunol (2015) 8(2):265-78. doi:10.1038/mi.2014.64

104. Nakamura K, Kitani A, Strober W. Cell contact-dependent immunosuppression by $\mathrm{CD} 4(+) \mathrm{CD} 25(+)$ regulatory $\mathrm{T}$ cells is mediated by cell surface-bound transforming growth factor beta. J Exp Med (2001) 194(5):629-44. doi:10.1084/jem.194.5.629

105. Garside P, Steel M, Liew FY, Mowat AM. CD $4^{+}$but not $\mathrm{CD} 8^{+} \mathrm{T}$ cells are required for the induction of oral tolerance. Int Immunol (1995) 7:501-4. doi:10.1093/intimm/7.3.501

106. Chen Y, Inobe J, Weiner HL. Induction of oral tolerance to myelin basic protein in CD8-depleted mice: both $\mathrm{CD}^{+}$and $\mathrm{CD} 8^{+}$cells mediate active suppression. J Immunol (1995) 155:910-6.

107. Wohlfert EA, Callahan MK, Clark RB. Resistance to CD4+CD25+regulatory $\mathrm{T}$ cells and TGF-beta in Cbl-b ${ }^{-/}$mice. JImmunol (2004) 173:1059-65. doi:10.4049/jimmunol.173.2.1059

108. Oluwole OO, DePaz HA, Adeyeri A, Jin M-X, Hardy MA, Oluwole SF. Role of $\mathrm{CD}^{+} \mathrm{CD}_{2} 5^{+}$regulatory $\mathrm{T}$ cells from naive host thymus in the induction of acquired transplant tolerance by immunization with allo-major histocompatibility complex peptide.1. Transplantation (2003) 75:1136-42. doi:10.1097/01.TP.0000062842.47597.13

109. Wilczynski JR, Radwan M, Kalinka J. The characterization and role of regulatory T cells in immune reactions. Front Biosci (2008) 13:2266-74. doi: $10.2741 / 2841$

110. Edinger M, Hoffmann P, Ermann J, Drago K, Fathman CG, Strober S, et al. $\mathrm{CD} 4^{+} \mathrm{CD} 25^{+}$regulatory $\mathrm{T}$ cells preserve graft-versus-tumor activity while inhibiting graft-versus-host disease after bone marrow transplantation. Nat Med (2003) 9:1144-50. doi:10.1038/nm915

111. Zeiser R, Nguyen VH, Beilhack A, Buess M, Schulz S, Baker J, et al. Inhibition of $\mathrm{CD}^{+} \mathrm{CD}^{+} 5^{+}$regulatory T-cell function by calcineurin-dependent interleukin-2 production. Blood (2006) 108:390-9. doi:10.1182/blood-200601-0329

112. Magenau JM, Qin X, Tawara I, Rogers CE, Schlough M, Bickley D, et al. Frequency of $\mathrm{CD} 44^{+} \mathrm{CD} 25^{\text {hi }} \mathrm{FOXP}^{+}$regulatory $\mathrm{T}$ cells has diagnostic and prognostic value as a biomarker for acute graft-versus-host-disease. Biol Blood Marrow Transplant (2010) 16:907-14. doi:10.1016/j.bbmt.2009.12.016

113. Zheng SG, Meng L, Wang JH, Watanabe M, Barr ML, Cramer DV, et al. Transfer of regulatory $\mathrm{T}$ cells generated ex vivo modifies graft rejection through induction of tolerogenic $\mathrm{CD} 4{ }^{+} \mathrm{CD} 25^{+}$cells in the recipient. Int Immunol (2006) 18:279-89. doi:10.1093/intimm/dxh368

114. Gagliani N, Gregori S, Jofra T, Valle A, Stabilini A, Rothstein DM, et al. Rapamycin combined with anti-CD45RB mAb and IL-10 or with G-CSF induces tolerance in a stringent mouse model of islet transplantation. PLoS One (2011) 6:e28434. doi:10.1371/journal.pone.0028434

115. Gagliani N, Jofra T, Valle A, Stabilini A, Morsiani C, Gregori S, et al. Transplant tolerance to pancreatic islets is initiated in the graft and sustained in the spleen. Am J Transplant (2013) 13:1963-75. doi:10.1111/ajt.12333

116. Feng G, Wood KJ, Bushell A. Interferon- $\gamma$ conditioning ex vivo generates $\mathrm{CD} 25^{+} \mathrm{CD} 62 \mathrm{~L}^{+} \mathrm{FOXP} 3^{+}$regulatory $\mathrm{T}$ cells that prevent allograft rejection: potential avenues for cellular therapy. Transplantation (2008) 86:578-89. doi:10.1097/TP.0b013e3181806a60

117. Feng G, Gao W, Strom TB, Oukka M, Francis RS, Wood KJ, et al. Exogenous IFN- $\gamma$ ex vivo shapes the alloreactive T-cell repertoire by inhibition of Th17 responses and generation of functional FOXP $3^{+}$regulatory T cells. Eur J Immunol (2008) 38:2512-27. doi:10.1002/eji.200838411

118. Warnecke G, Feng G, Goto R, Nadig SN, Francis R, Wood KJ, et al. $\mathrm{CD}^{+}$regulatory $\mathrm{T}$ cells generated in vitro with IFN- $\gamma$ and allogeneic APC inhibit transplant arteriosclerosis. Am J Pathol (2010) 177:464-72. doi:10.2353/ajpath.2010.090292

119. Zhang C, Shan J, Lu J, Huang Y, Feng L, Long D, et al. Rapamycin in combination with donor-specific $\mathrm{CD} 4^{+} \mathrm{CD} 25^{+}$Treg cells amplified in vitro might be realize the immune tolerance in clinical organ transplantation. Cell Immunol (2010) 264:111-3. doi:10.1016/j.cellimm.2010.05.014

120. Kim KW, Chung BH, Kim B-M, Cho M-L, Yang CW. The effect of mammalian target of rapamycin inhibition on T helper type 17 and regulatory $\mathrm{T}$ cell differentiation in vitro and in vivo in kidney transplant recipients. Immunology (2014) 144:68-78. doi:10.1111/imm.12351

121. Stallone G, Infante B, Schena A, Battaglia M, Ditonno P, Loverre A, et al. Rapamycin for treatment of chronic allograft nephropathy in renal transplant patients. J Am Soc Nephrol (2005) 16:3755-62. doi:10.1681/ASN.2005060635

122. Hariharan S, Johnson CP, Bresnahan BA, Taranto SE, McIntosh MJ, Stablein D. Improved graft survival after renal transplantation in the United States, 1988 to 1996. N Engl J Med (2000) 342:605-12. doi:10.1056/ NEJM200003023420901

123. Calne RY, Alexandre GP, Murray JE. A study of the effects of drugs in prolonging survival of homologous renal transplants in dogs. Ann N Y Acad Sci (1962) 99:743-61. doi:10.1111/j.1749-6632.1962.tb45358.x

124. Nankivell BJ, Borrows RJ, Fung CLS, O'Connell PJ, Allen RDM, Chapman JR. The natural history of chronic allograft nephropathy. N Engl J Med (2003) 349:2326-33. doi:10.1056/NEJMoa020009

125. Kreijveld E, Koenen HJPM, Hilbrands LB, Joosten I. Ex vivo expansion of human $\mathrm{CD} 4^{+} \mathrm{CD} 25^{\text {high }}$ regulatory $\mathrm{T}$ cells from transplant recipients permits functional analysis of small blood samples. JImmunol Methods (2006) 314:103-13. doi:10.1016/j.jim.2006.06.001

126. Killebrew JR, Perdue N, Kwan A, Thornton AM, Shevach EM, Campbell DJA. Self-reactive TCR drives the development of FOXP $3^{+}$regulatory T cells that prevent autoimmune disease. J Immunol (2011) 187:861-9. doi:10.4049/ jimmunol.1004009

127. Viglietta V, Baecher-Allan C, Weiner HL, Hafler DA. Loss of functional suppression by $\mathrm{CD} 4^{+} \mathrm{CD} 25^{+}$regulatory $\mathrm{T}$ cells in patients with multiple sclerosis. J Exp Med (2004) 199:971-9. doi:10.1084/jem.20031579

128. Venken K, Hellings N, Thewissen M, Somers V, Hensen K, Rummens JL, et al. Compromised CD4+ CD25(high) regulatory T-cell function in patients with relapsing-remitting multiple sclerosis is correlated with a reduced frequency of FOXP3-positive cells and reduced FOXP3 expression at the single-cell level. Immunology (2008) 123(1):79-89. doi:10.1111/j.1365-2567.2007.02690.x

129. Jamshidian A, Shaygannejad V, Pourazar A, Zarkesh-Esfahani SH, Gharagozloo M. Biased Treg/Th17 balance away from regulatory toward inflammatory phenotype in relapsed multiple sclerosis and its correlation with severity of symptoms. J Neuroimmunol (2013) 262(1-2):106112. doi:10.1016/j.jneuroim.2013.06.007

130. Tejera-Alhambra M, Alonso B, Teijeiro R, Ramos-Medina R, Aristimuño C, Valor $\mathrm{L}$, et al. Perforin expression by CD4+ regulatory T cells increases at multiple sclerosis relapse: sex differences. Int J Mol Sci (2012) 13(6):669866710. doi:10.3390/ijms 13066698

131. Fujii C, Kondo T, Ochi H, Okada Y, Hashi Y, Adachi T, et al. Altered T cell phenotypes associated with clinical relapse of multiple sclerosis patients receiving fingolimod therapy. Sci Rep (2016) 6:35314. doi:10.1038/srep35314

132. Oh U, Blevins G, Griffith C, Richert N, Maric D, Lee CR, et al. Regulatory $\mathrm{T}$ cells are reduced during anti-CD25 antibody treatment of multiple sclerosis. Arch Neurol (2009) 66(4):471-9. doi:10.1001/archneurol.2009.16

133. Van Amelsfort JM, Jacobs KM, Bijlsma JW, Lafeber FP, Taams LS. CD4(+) $\mathrm{CD} 25(+)$ regulatory $\mathrm{T}$ cells in rheumatoid arthritis: differences in the presence, phenotype, and function between peripheral blood and synovial fluid. Arthritis Rheum (2004) 50(9):2775-85. doi:10.1002/art.20499

134. Kim JR, Chae JN, Kim SH, Ha JS. Subpopulations of regulatory T cells in rheumatoid arthritis, systemic lupus erythematosus, and Behcet's disease. J Korean Med Sci (2012) 27(9):1009-13. doi:10.3346/jkms.2012.27.9.1009

135. Lawson CA, Brown AK, Bejarano V, Douglas SH, Burgoyne $\mathrm{CH}$, Greenstein AS, et al. Early rheumatoid arthritis is associated with a deficit in the CD4+CD25high regulatory $\mathrm{T}$ cell population in peripheral blood. Rheumatology (2006) 45(10):1210-7. doi:10.1093/rheumatology/kel089

136. Wang W, Shao S, Jiao Z, Guo M, Xu H, Wang S. The Th17/Treg imbalance and cytokine environment in peripheral blood of patients with rheumatoid arthritis. Rheumatol Int (2012) 32(4):887-93. doi:10.1007/s00296-010-1710-0

137. Walter GJ, Fleskens V, Frederiksen KS, Rajasekhar M, Menon B, Gerwien JG, et al. Phenotypic, functional, and gene expression profiling of peripheral CD45RA+ and CD45RO+ CD4+CD25+CD127(low) Treg cells in patients with chronic rheumatoid arthritis. Arthritis Rheumatol (2016) 68(1):103-16. doi:10.1002/art.39408 
138. Ehrenstein MR, Evans JG, Singh A, Moore S, Warnes G, Isenberg DA, et al. Compromised function of regulatory $\mathrm{T}$ cells in rheumatoid arthritis and reversal by anti-TNFalpha therapy. J Exp Med (2004) 200(3):277-85. doi:10.1084/jem.20040165

139. Nadkarni S, Mauri C, Ehrenstein MR. Anti-TNF-alpha therapy induces a distinct regulatory $\mathrm{T}$ cell population in patients with rheumatoid arthritis via TGF-beta. J Exp Med (2007) 204(1):33-9. doi:10.1084/jem.20061531

140. Lucas JL, Mirshahpanah P, Haas-Stapleton E, Asadullah K, Zollner TM, Numerof RP. Induction of Foxp3+ regulatory T cells with histone deacetylase inhibitors. Cell Immunol (2009) 257(1-2):97-104. doi:10.1016/j. cellimm.2009.03.004

141. Yang J, Chu Y, Yang X, Gao D, Zhu L, Yang X, et al. Th17 and natural Treg cell population dynamics in systemic lupus erythematosus. Arthritis Rheum (2009) 60(5):1472-83. doi:10.1002/art.24499

142. Legorreta-Haquet MV, Chávez-Rueda K, Chávez-Sánchez L, CerveraCastillo H, Zenteno-Galindo E, Barile-Fabris L, et al. Function of Treg cells decreased in patients with systemic lupus erythematosus due to the effect of prolactin. Medicine (2016) 95(5):e2384. doi:10.1097/MD.0000000000002384

143. Huang H, Sun W, Liang Y, Long XD, Peng Y, Liu Z, et al. CD (+)(4)CD(+)(25) Treg cells in thrombotic thrombocytopenic purpura associated with systemic lupus erythematosus patients. Ren Fail (2014) 36(8):1263-7. doi:10.3109/08 86022X.2014.934649

144. Wang G, Lai FMM, Tam LS, Li EKM, Kwan BCH, Chow KM, et al. Urinary FOXP3 mRNA in patients with lupus nephritis-relation with disease activity and treatment response. Rheumatology (2009) 48:755-60. doi:10.1093/ rheumatology/kep074

145. Handono K, Firdausi SN, Pratama MZ, Endharti AT, Kalim H. Vitamin A improve Th17 and Treg regulation in systemic lupus erythematosus. Clin Rheumatol (2016) 35(3):631-8. doi:10.1007/s10067-016-3197-x

146. Chandrasekaran U, Yi W, Gupta S, Weng CH, Giannopoulou E, Chinenov Y, et al. Regulation of effector Treg cells in murine lupus. Arthritis Rheumatol (2016) 68(6):1454-66. doi:10.1002/art.39599

147. Wang D, Huang S, Yuan X, Liang J, Xu R, Yao G, et al. The regulation of the Treg/Th17 balance by mesenchymal stem cells in human systemic lupus erythematosus. Cell Mol Immunol (2015) 14(5):423-31. doi:10.1038/cmi.2015.89

148. Zuber J, Viguier M, Lemaitre F, Senée V, Patey N, Elain G, et al. Severe $\mathrm{FOXP}^{+}$and naïve $\mathrm{T}$ lymphopenia in a non-IPEX form of autoimmune enteropathy combined with an immunodeficiency. Gastroenterology (2007) 132:1694-704. doi:10.1053/j.gastro.2007.02.034

149. Herkel J. Regulatory $\mathrm{T}$ cells in hepatic immune tolerance and autoimmune liver diseases. Dig Dis (2015) 33:70-4. doi:10.1159/000440750

150. Zhang W, Sharma R, Ju ST, He XS, Tao Y, Tsuneyama K, et al. Deficiency in regulatory $\mathrm{T}$ cells results in development of antimitochondrial antibodies and autoimmune cholangitis. Hepatology (2009) 49:545-52. doi:10.1002/ hep. 22651

151. Longhi MS, Hussain MJ, Mitry RR, Arora SK, Mieli-Vergani G, Vergani D, et al. Functional study of $\mathrm{CD} 4{ }^{+} \mathrm{CD} 25^{+}$regulatory $\mathrm{T}$ cells in health and autoimmune hepatitis. J Immunol (2006) 176:4484-91. doi:10.4049/ jimmunol.176.7.4484

152. Taubert R, Hardtke-Wolenski M, Noyan F, Wilms A, Baumann AK, Schlue J, et al. Intrahepatic regulatory $\mathrm{T}$ cells in autoimmune hepatitis are associated with treatment response and depleted with current therapies. JHepatol (2014) 61:1106-14. doi:10.1016/j.jhep.2014.05.034

153. Oo YH, Adams DH. Regulatory T cells and autoimmune hepatitis: what happens in the liver stays in the liver. J Hepatol (2014) 61:973-5. doi:10.1016/j. jhep.2014.08.005

154. Peiseler M, Sebode M, Franke B, Wortmann F, Schwinge D, Quaas A, et al. $\mathrm{FOXP}^{+}$regulatory $\mathrm{T}$ cells in autoimmune hepatitis are fully functional and not reduced in frequency. J Hepatol (2012) 57:125-32. doi:10.1016/j. jhep.2012.02.029

155. Akdis M, Verhagen J, Taylor A, Karamloo F, Karagiannidis C, Crameri R, et al. Immune responses in healthy and allergic individuals are characterized by a fine balance between allergen-specific T regulatory 1 and T helper 2 cells. J Exp Med (2004) 199:1567-75. doi:10.1084/jem.20032058

156. Fyhrquist N, Lehtimäki S, Lahl K, Savinko T, Lappeteläinen A-M, Sparwasser $\mathrm{T}$, et al. FOXP $3^{+}$cells control Th2 responses in a murine model of atopic dermatitis. J Invest Dermatol (2012) 132:1672-80. doi:10.1038/jid.2012.40
157. Baru AM, Hartl A, Lahl K, Krishnaswamy JK, Fehrenbach H, Yildirim AÖ, et al. Selective depletion of FOXP3 ${ }^{+}$Treg during sensitization phase aggravates experimental allergic airway inflammation. Eur J Immunol (2010) 40:2259-66. doi:10.1002/eji.200939972

158. Strömbeck A, Rabe H, Lundell AC, Andersson K, Johansen S, Adlerberth I, et al. High proportions of FOXP3 ${ }^{(+)} \mathrm{CD} 25^{\text {(high) }} \mathrm{T}$ cells in neonates are positively associated with allergic sensitization later in childhood. Clin Exp Allergy (2014) 44:940-52. doi:10.1111/cea.12290

159. Radulovic S, Jacobson MR, Durham SR, Nouri-Aria KT. Grass pollen immunotherapy induces FOXP3-expressing $\mathrm{CD} 4^{+} \mathrm{CD} 25^{+}$cells in the nasal mucosa. J Allergy Clin Immunol (2008) 121: 1467-72, 1472.e1. doi:10.1016/j. jaci.2008.03.013

160. Krogulska A, Borowiec M, Polakowska E, Dynowski J, Mlynarski W, Wasowska-Krolikowska K. FOXP3, IL-10, and TGF-beta genes expression in children with IgE-dependent food allergy. J Clin Immunol (2011) 31:205-15. doi:10.1007/s10875-010-9487-1

161. Stelmaszczyk-Emmel A, Zawadzka-Krajewska A, Głodkowska-Mrówka E, Demkow U. FOXP3 Tregs response to sublingual allergen specific immunotherapy in children depends on the manifestation of allergy. J Immunol Res (2015) 2015:731381. doi:10.1155/2015/731381

162. Pardoll DM. The blockade of immune checkpoints in cancer immunotherapy. Nat Rev Cancer (2012) 12:252-64. doi:10.1038/nrc3239

163. Omland SH, Nielsen PS, Gjerdrum LM, Gniadecki R. Immunosuppressive environment in basal cell carcinoma: the role of regulatory T-cells. Acta Derm Venereol (2016) 96(7):917-21. doi:10.2340/00015555-2440

164. Sasaki A, Tanaka F, Mimori K, Inoue H, Kai S, Shibata K, et al. Prognostic value of tumor-infiltrating $\mathrm{FOXP}^{+}$regulatory $\mathrm{T}$ cells in patients with hepatocellular carcinoma. Eur J Surg Oncol (2008) 34:173-9. doi:10.1016/j. ejso.2007.08.008

165. Ghebeh H, Barhoush E, Tulbah A, Elkum N, Al-Tweigeri T, Dermime S. FOXP $^{+}$Tregs and B7-H1+/PD-1+ T lymphocytes co-infiltrate the tumor tissues of high-risk breast cancer patients: implication for immunotherapy. BMC Cancer (2008) 23:57. doi:10.1186/1471-2407-8-57

166. Jiang Y, Du Z, Yang F, Di Y, Li J, Zhou Z, et al. FOXP3 $3^{+}$lymphocyte density in pancreatic cancer correlates with lymph node metastasis. PLoS One (2014) 9:e106741. doi:10.1371/journal.pone.0106741

167. Luo Q, Zhang S, Wei H, Pang X, Zhang H. Roles of FOXP3 in the occurrence and development of cervical cancer. Int J Clin Exp Pathol (2015) 8:8717-30.

168. Zhao S, Jiang T, Zhang L, Yang H, Liu X, Jia Y, et al. Clinicopathological and prognostic significance of regulatory $\mathrm{T}$ cells in patients with non-small cell lung cancer: a systematic review with meta-analysis. Oncotarget (2016) 7(24):36065-73. doi:10.18632/oncotarget.9130

169. Liu Z, Huang Q, Liu G, Dang L, Chu D, Tao K, et al. Presence of FOXP3(+) Treg cells is correlated with colorectal cancer progression. Int J Clin Exp Med (2014) 7:1781-5

170. Zhang S, Ke X, Zeng S, Wu M, Lou J, Wu L, et al. Analysis of CD8 ${ }^{+}$Treg cells in patients with ovarian cancer: a possible mechanism for immune impairment. Cell Mol Immunol (2015) 12:580-91. doi:10.1038/cmi.2015.57

171. Yoshii M, Tanaka H, Ohira M, Muguruma K, Iwauchi T, Lee T, et al. Expression of Forkhead box P3 in tumour cells causes immunoregulatory function of signet ring cell carcinoma of the stomach. Br J Cancer (2012) 106:1668-74. doi:10.1038/bjc.2012.141

172. Deng B, Zhu J-M, Wang Y, Liu T-T, Ding Y-B, Xiao W-M, et al. Intratumor hypoxia promotes immune tolerance by inducing regulatory $\mathrm{T}$ cells via TGF- $\beta 1$ in gastric cancer. PLoS One (2013) 8:e63777. doi:10.1371/journal. pone. 0063777

173. Hansen W, Hutzler M, Abel S, Alter C, Stockmann C, Kliche S, et al. Neuropilin 1 deficiency on CD4+Foxp3+ regulatory T cells impairs mouse melanoma growth. J Exp Med (2012) 209(11):2001-16. doi:10.1084/jem.20111497

174. Delgoffe GM, Woo SR, Turnis ME, Gravano DM, Guy C, Overacre AE, et al. Stability and function of regulatory $\mathrm{T}$ cells is maintained by a neuropilin-1-semaphorin-4a axis. Nature (2013) 501(7466):252-6. doi:10.1038/ nature 12428

175. Zuo T, Wang L, Morrison C, Chang X, Zhang H, Li W, et al. FOXP3 is an $\mathrm{X}$-linked breast cancer suppressor gene and an important repressor of the HER-2/ErbB2 oncogene. Cell (2007) 129(7):1275-86. doi:10.1016/j. cell.2007.04.034 
176. Wang L, Liu R, Li W, Chen C, Katoh H, Chen G-Y, et al. Somatic single hits inactivate the X-linked tumor suppressor FOXP3 in the prostate. Cancer Cell (2009) 16:336-46. doi:10.1016/j.ccr.2009.08.016

177. Hansson GK. Inflammation, atherosclerosis, and coronary artery disease. $N$ Engl J Med (2005) 352:1685-95. doi:10.1056/NEJMra043430

178. van Es T, van Puijvelde GH, Foks AC, Habets KL, Bot I, Gilboa E, et al. Vaccination against $\mathrm{FOXP}^{(+)}$regulatory $\mathrm{T}$ cells aggravates atherosclerosis. Atherosclerosis (2010) 209:74-80. doi:10.1016/j.atherosclerosis.2009.08.041

179. Klingenberg R, Gerdes N, Badeau RM, Gisterå A, Strodthoff D, Ketelhuth DFJ, et al. Depletion of FOXP3 ${ }^{+}$regulatory $\mathrm{T}$ cells promotes hypercholesterolemia and atherosclerosis. J Clin Invest (2013) 123:1323-34. doi:10.1172/ JCI63891

180. Foks AC, Frodermann V, ter Borg M, Habets KLL, Bot I, Zhao Y, et al. Differential effects of regulatory $\mathrm{T}$ cells on the initiation and regression of atherosclerosis. Atherosclerosis (2011) 218:53-60. doi:10.1016/j. atherosclerosis.2011.04.029

181. Mor A, Luboshits G, Planer D, Keren G, George J. Altered status of $\mathrm{CD} 4{ }^{+} \mathrm{CD} 25^{+}$regulatory $\mathrm{T}$ cells in patients with acute coronary syndromes. Eur Heart J (2006) 27:2530-7. doi:10.1093/eurheartj/ehl222

182. de Boer OJ, van der Meer JJ, Teeling P, van der Loos CM, van der Wal AC. Low numbers of FOXP3 positive regulatory $\mathrm{T}$ cells are present in all developmental stages of human atherosclerotic lesions. PLoS One (2007) 2:e779. doi:10.1371/journal.pone.0000779

183. Kofler S, Sisic Z, Shvets N, Lohse P, Weis M. Expression of circulatory dendritic cells and regulatory T-cells in patients with different subsets of coronary artery disease. J Cardiovasc Pharmacol (2011) 57:542-9. doi:10.1097/ FJC.0b013e3182124c53

184. Onishi Y, Fehervari Z, Yamaguchi T, Sakaguchi S. FOXP3 ${ }^{+}$natural regulatory $\mathrm{T}$ cells preferentially form aggregates on dendritic cells in vitro and actively inhibit their maturation. Proc Natl Acad Sci U S A (2008) 105:10113-8. doi:10.1073/pnas.0711106105

185. Suvas S, Kumaraguru U, Pack CD, Lee S, Rouse BT. CD4 ${ }^{+}$CD25 $5^{+}$T cells regulate virus-specific primary and memory $\mathrm{CD} 8^{+} \mathrm{T}$ cell responses. J Exp Med (2003) 198:889-901. doi:10.1084/jem.20030171

186. Veiga-Parga T, Sehrawat S, Rouse BT. Role of regulatory T cells during virus infection. Immunol Rev (2013) 255:182-96. doi:10.1111/imr.12085

187. Sharma S, Rajasagi NK, Veiga-Parga T, Rouse BT. Herpes virus entry mediator (HVEM) modulates proliferation and activation of regulatory $\mathrm{T}$ cells following HSV-1 infection. Microbes Infect (2014) 16:648-60. doi:10.1016/j. micinf.2014.06.005

188. Lund JM, Hsing L, Pham TT, Rudensky AY. Coordination of early protective immunity to viral infection by regulatory T cells. Science (2008) 320(5880):1220-4. doi:10.1126/science.1155209

189. Nagata DE, Ting HA, Cavassani KA, Schaller MA, Mukherjee S, Ptaschinski $\mathrm{C}$, et al. Epigenetic control of FOXP3 by SMYD3 H3K4 histone methyltransferase controls iTreg development and regulates pathogenic T-cell responses during pulmonary viral infection. Mucosal Immunol (2015) 8:1131-43. doi:10.1038/mi.2015.4

190. Ferrarini G, Borghetti P, De Angelis E, Ferrari L, Canelli E, Catella A, et al. Immunoregulatory signal FOXP3, cytokine gene expression and IFN- $\gamma$ cell responsiveness upon porcine reproductive and respiratory syndrome virus (PRRSV) natural infection. Res Vet Sci (2015) 103:96-102. doi:10.1016/j. rvsc.2015.09.018

191. Miller AD, Blutt SE, Conner ME. FOXP $3^{+}$regulatory T cells are not important for rotavirus clearance or the early antibody response to rotavirus. Microbes Infect (2014) 16:67-72. doi:10.1016/j.micinf.2013.09.004

192. Bedoya F, Cheng GS, Leibow A, Zakhary N, Weissler K, Garcia V, et al. Viral antigen induces differentiation of $\mathrm{FOXP}^{+}$natural regulatory $\mathrm{T}$ cells in influenza virus-infected mice. J Immunol (2013) 190:6115-25. doi:10.4049/ jimmunol.1203302

193. Betts RJ, Prabhu N, Ho AW, Lew FC, Hutchinson PE, Rotzschke O, et al. Influenza A virus infection results in a robust, antigen-responsive, and widely disseminated FOXP3 ${ }^{+}$regulatory T cell response. J Virol (2012) 86:2817-25. doi:10.1128/JVI.05685-11

194. Williams-Bey Y, Jiang J, Murasko DM. Expansion of regulatory T cells in aged mice following influenza infection. Mech Ageing Dev (2011) 132:163-70. doi:10.1016/j.mad.2011.03.001

195. Brincks EL, Roberts AD, Cookenham T, Sell S, Kohlmeier JE, Blackman $\mathrm{MA}$, et al. Antigen-specific memory regulatory $\mathrm{CD}^{+} \mathrm{FOXP}^{+} \mathrm{T}$ cells control memory responses to influenza virus infection. J Immunol (2013) 190:3438-46. doi:10.4049/jimmunol.1203140

196. Leon B, Bradley JE, Lund FE, Randall TD, Ballesteros-Tato A. FOXP3 ${ }^{+}$ regulatory $\mathrm{T}$ cells promote influenza-specific Tfh responses by controlling IL-2 availability. Nat Commun (2014) 5:3495. doi:10.1038/ncomms4495

197. Surls J, Nazarov-Stoica C, Kehl M, Casares S, Brumeanu TD. Differential effect of $\mathrm{CD}^{+}{ }^{+} \mathrm{FOXP}^{+}{ }^{+} \mathrm{T}$-regulatory cells on the $\mathrm{B}$ and $\mathrm{T}$ helper cell responses to influenza virus vaccination. Vaccine (2010) 28:7319-30. doi:10.1016/j. vaccine.2010.08.074

198. Vukmanovic-Stejic M, Zhang Y, Cook JE, Fletcher JM, McQuaid A, Masters $\mathrm{JE}$, et al. Human $\mathrm{CD} 4{ }^{+} \mathrm{CD} 25^{\text {hi }} \mathrm{FOXP} 3^{+}$regulatory $\mathrm{T}$ cells are derived by rapid turnover of memory populations in vivo. J Clin Invest (2006) 116:2423-33. doi:10.1172/JCI28941C1

199. Satou Y, Utsunomiya A, Tanabe J, Nakagawa M, Nosaka K, Matsuoka M. HTLV-1 modulates the frequency and phenotype of FOXP $3^{+} \mathrm{CD} 4{ }^{+}$ $\mathrm{T}$ cells in virus-infected individuals. Retrovirology (2012) 9:46. doi:10.1186/1742-4690-9-46

200. Chen S, Ishii N, Ine S, Ikeda S, Fujimura T, Ndhlovu LC, et al. Regulatory T cell-like activity of FOXP3 ${ }^{+}$adult T cell leukemia cells. Int Immunol (2006) 18:269-77. doi:10.1093/intimm/dxh366

201. Torres-Cabala CA, Curry JL, Li Ning Tapia EM, Ramos C, Tetzlaff MT, Prieto VG, et al. HTLV-1-associated infective dermatitis demonstrates low frequency of FOXP3-positive T-regulatory lymphocytes. J Dermatol Sci (2015) 77:150-5. doi:10.1016/j.jdermsci.2015.01.003

202. Chissumba RM, Silva-Barbosa SD, Augusto A, Maueia C, Mabunda N, Gudo ES Jr, et al. CD $4^{(+)} \mathrm{CD} 25^{\text {(High) }}$ Treg cells in HIV/HTLV co-infected patients with neuropathy: high expression of Alpha4 integrin and lower expression of FOXP3 transcription factor. BMC Immunol (2015) 16:52. doi:10.1186/ s12865-015-0116-x

203. Zhao T, Satou Y, Sugata K, Miyazato P, Green PL, Imamura T, et al. HTLV-1 bZIP factor enhances TGF-beta signaling through p300 coactivator. Blood (2011) 118:1865-76. doi:10.1182/blood-2010-12-326199

204. Arnulf B, Villemain A, Nicot C, Mordelet E, Charneau P, Kersual J, et al. Human T-cell lymphotropic virus oncoprotein Tax represses TGF-beta 1 signaling in human $\mathrm{T}$ cells via c-Jun activation: a potential mechanism of HTLV-I leukemogenesis. Blood (2002) 100:4129-38. doi:10.1182/ blood-2001-12-0372

205. Anderson MR, Enose-Akahata Y, Massoud R, Ngouth N, Tanaka Y, Oh U, et al. Epigenetic modification of the FOXP3 TSDR in HAM/TSP decreases the functional suppression of Tregs. JNeuroimmune Pharmacol (2014) 9:522-32. doi:10.1007/s11481-014-9547-z

206. Moreno-Fernandez ME, Rueda CM, Rusie LK, Chougnet CA. Regulatory T cells control HIV replication in activated T cells through a cAMP-dependent mechanism. Blood (2011) 117:5372-80. doi:10.1182/blood-2010-12-323162

207. Miles B, Miller SM, Folkvord JM, Kimball A, Chamanian M, Meditz AL, et al. Follicular regulatory $\mathrm{T}$ cells impair follicular T helper cells in HIV and SIV infection. Nat Commun (2015) 6:8608. doi:10.1038/ncomms 9608

208. Simonetta F, Bourgeois C. $\mathrm{CD}^{+} \mathrm{FOXP}^{+}$regulatory T-cell subsets in human immunodeficiency virus infection. Front Immunol (2013) 4:215. doi:10.3389/ fimmu.2013.00215

209. Abdel-Hameed EA, Ji H, Sherman KE, Shata MT. Epigenetic modification of FOXP3 in patients with chronic HIV infection. J Acquir Immune Defic Syndr (2014) 65:19-26. doi:10.1097/QAI.0b013e3182a1bca4

210. Apoil PA, Puissant B, Roubinet F, Abbal M, Massip P, Blancher A. FOXP3 mRNA levels are decreased in peripheral blood $\mathrm{CD}^{+}$lymphocytes from HIV-positive patients. JAcquir Immune Defic Syndr (2005) 39:381-5. doi:10.1097/01.qai.0000169662.30783.2d

211. Rehermann B, Nascimbeni M. Immunology of hepatitis B virus and hepatitis C virus infection. Nat Rev Immunol (2005) 5:215-29. doi:10.1038/nri1573

212. Xu D, Fu J, Jin L, Zhang H, Zhou C, Zou Z, et al. Circulating and liver resident $\mathrm{CD} 4{ }^{+} \mathrm{CD} 25^{+}$regulatory $\mathrm{T}$ cells actively influence the antiviral immune response and disease progression in patients with hepatitis B. Jimmunol (2006) 177:739-47. doi:10.4049/jimmunol.177.1.739

213. Stross L, Gunther J, Gasteiger G, Asen T, Graf S, Aichler M, et al. FOXP3 ${ }^{+}$ regulatory $\mathrm{T}$ cells protect the liver from immune damage and compromise virus control during acute experimental hepatitis B virus infection in mice. Hepatology (2012) 56:873-83. doi:10.1002/hep.25765

214. Stoop JN, van der Molen RG, Baan CC, van der Laan LJ, Kuipers EJ, Kusters JG, et al. Regulatory $\mathrm{T}$ cells contribute to the impaired immune response in 
patients with chronic hepatitis B virus infection. Hepatology (2005) 41:771-8. doi:10.1002/hep.20649

215. Yang G, Liu A, Xie Q, Guo TB, Wan B, Zhou B, et al. Association of $\mathrm{CD} 4{ }^{+} \mathrm{CD} 25^{+} \mathrm{FOXP}^{+}$regulatory $\mathrm{T}$ cells with chronic activity and viral clearance in patients with hepatitis B. Int Immunol (2007) 19:133-40. doi:10.1093/ intimm/dxl130

216. Bowen DG, Walker CM. Adaptive immune responses in acute and chronic hepatitis C virus infection. Nature (2005) 436:946-52. doi:10.1038/ nature 04079

217. Wedemeyer H, He XS, Nascimbeni M, Davis AR, Greenberg HB, Hoofnagle $\mathrm{JH}$, et al. Impaired effector function of hepatitis $\mathrm{C}$ virus-specific $\mathrm{CD} 8^{+}$ $\mathrm{T}$ cells in chronic hepatitis $\mathrm{C}$ virus infection. J Immunol (2002) 169:3447-58. doi:10.4049/jimmunol.169.6.3447

218. Ward SM, Fox BC, Brown PJ, Worthington J, Fox SB, Chapman RW, et al. Quantification and localisation of FOXP3 ${ }^{+}$T lymphocytes and relation to hepatic inflammation during chronic HCV infection. J Hepatol (2007) 47:316-24. doi:10.1016/j.jhep.2007.03.023

219. Heeg MH, Ulsenheimer A, Gruner NH, Zachoval R, Jung MC, Gerlach JT, et al. FOXP3 expression in hepatitis $\mathrm{C}$ virus-specific $\mathrm{CD} 4^{+} \mathrm{T}$ cells during acute hepatitis C. Gastroenterology (2009) 137: 1280-8.e1-6. doi:10.1053/j. gastro.2009.06.059

220. Bolacchi F, Sinistro A, Ciaprini C, Demin F, Capozzi M, Carducci FC, et al. Increased hepatitis $\mathrm{C}$ virus (HCV)-specific $\mathrm{CD} 4^{(+)} \mathrm{CD} 25^{(+)}$regulatory T lymphocytes and reduced HCV-specific $\mathrm{CD} 4^{(+)} \mathrm{T}$ cell response in $\mathrm{HCV}$-infected patients with normal versus abnormal alanine aminotransferase levels. Clin Exp Immunol (2006) 144:188-96. doi:10.1111/j.1365-2249.2006.03048.x

221. Amoras Eda S, Gomes ST, Freitas FB, Santana BB, Ishak G, Ferreira de Araujo MT, et al. Intrahepatic mRNA expression of FAS, FASL, and FOXP3 genes is associated with the pathophysiology of chronic HCV infection. PLoS One (2016) 11:e0156604. doi:10.1371/journal.pone.0156604

222. Mills KH. Regulatory T cells: friend or foe in immunity to infection? Nat Rev Immunol (2004) 4:841-55. doi:10.1038/nri1485

223. Wisnoski N, Chung CS, Chen Y, Huang X, Ayala A. The contribution of CD4 $4^{+}$ $\mathrm{CD}^{2} 5^{+}$T-regulatory-cells to immune suppression in sepsis. Shock (2007) 27:251-7. doi:10.1097/01.shk.0000239780.33398.e4

224. Dai J, Liu B, Li Z. Regulatory T cells and Toll-like receptors: what is the missing link? Int Immunopharmacol (2009) 9:528-33. doi:10.1016/j. intimp.2009.01.027

225. Venet F, Chung CS, Monneret G, Huang X, Horner B, Garber M, et al. Regulatory T cell populations in sepsis and trauma. JLeukoc Biol (2008) 83:523-35. doi:10.1189/jlb.0607371

226. Li L, Lao SH, Wu CY. Increased frequency of $\mathrm{CD} 4^{(+)} \mathrm{CD} 25^{(\text {high) }}$ Treg cells inhibit BCG-specific induction of IFN-gamma by $\mathrm{CD} 4^{(+)} \mathrm{T}$ cells from TB patients. Tuberculosis (Edinb) (2007) 87:526-34. doi:10.1016/j.tube.2007.07.004

227. Venkatasubramanian S, Dhiman R, Paidipally P, Cheekatla SS, Tripathi D, Welch E, et al. A rho GDP dissociation inhibitor produced by apoptotic T-cells inhibits growth of Mycobacterium tuberculosis. PLoS Pathog (2015) 11:e1004617. doi:10.1371/journal.ppat.1004617

228. Holla S, Stephen-Victor E, Prakhar P, Sharma M, Saha C, Udupa V, et al. Mycobacteria-responsive sonic hedgehog signaling mediates programmed death-ligand 1- and prostaglandin E2-induced regulatory T cell expansion. Sci Rep (2016) 6:24193. doi:10.1038/srep24193

229. Oertli M, Sundquist M, Hitzler I, Engler DB, Arnold IC, Reuter S, et al. DC-derived IL-18 drives Treg differentiation, murine Helicobacter pylorispecific immune tolerance, and asthma protection. J Clin Invest (2012) 122:1082-96. doi:10.1172/JCI61029

230. Harris PR, Wright SW, Serrano C, Riera F, Duarte I, Torres J, et al. Helicobacterpylori gastritis in children is associated with a regulatory T-cell response. Gastroenterology (2008) 134:491-9. doi:10.1053/j. gastro.2007.11.006

231. Fehri F, Koch M, Belogolova E, Khalil H, Bolz C, Kalali B, et al. Helicobacter pylori induces miR-155 in T cells in a cAMP-FOXP3-dependent manner. PLoS One (2010) 5:e9500. doi:10.1371/journal.pone.0009500

232. Arnold IC, Lee JY, Amieva MR, Roers A, Flavell RA, Sparwasser T, et al. Tolerance rather than immunity protects from Helicobacter pylori-induced gastric pre-neoplasia. Gastroenterology (2011) 140:199-209. doi:10.1053/j. gastro.2010.06.047
233. Kamada N, Nunez G. Regulation of the immune system by the resident intestinal bacteria. Gastroenterology (2014) 146:1477-88. doi:10.1053/j. gastro.2014.01.060

234. Strauch UG, Obermeier F, Grunwald N, Gurster S, Dunger N, Schultz M, et al. Influence of intestinal bacteria on induction of regulatory $\mathrm{T}$ cells: lessons from a transfer model of colitis. Gut (2005) 54:1546-52. doi:10.1136/ gut.2004.059451

235. Atarashi K, Tanoue T, Oshima K, Suda W, Nagano Y, Nishikawa H, et al. Treg induction by a rationally selected mixture of Clostridia strains from the human microbiota. Nature (2013) 500:232-6. doi:10.1038/nature12331

236. Atarashi K, Tanoue T, Shima T, Imaoka A, Kuwahara T, Momose $\mathrm{Y}$, et al. Induction of colonic regulatory $\mathrm{T}$ cells by indigenous Clostridium species. Science (2011) 331:337-41. doi:10.1126/science.1198469

237. Smith PM, Howitt MR, Panikov N, Michaud M, Gallini CA, Bohlooly-Y $\mathrm{M}$, et al. The microbial metabolites, short-chain fatty acids, regulate colonic Treg cell homeostasis. Science (2013) 341(6145):569-73. doi:10.1126/ science. 1241165

238. Furusawa Y, Obata Y, Fukuda S, Endo TA, Nakato G, Takahashi D, et al. Commensal microbe-derived butyrate induces the differentiation of colonic regulatory T cells. Nature (2013) 504:446-50. doi:10.1038/nature12721

239. Arpaia N, Campbell C, Fan X, Dikiy S, Van der Veeken J, deRoos P, et al. Metabolites produced by commensal bacteria promote peripheral regulatory T-cell generation. Nature (2013) 504(7480):451-5. doi:10.1038/ nature 12726

240. Chinen T, Volchkov PY, Chervonsky AV, Rudensky AY. A critical role for regulatory $\mathrm{T}$ cell-mediated control of inflammation in the absence of commensal microbiota. J Exp Med (2010) 207(11):2323-30. doi:10.1084/jem.20101235

241. Hohl TM, Rivera A, Pamer EG. Immunity to fungi. Curr Opin Immunol (2006) 18:465-72. doi:10.1016/j.coi.2006.05.003

242. Bettelli E, Carrier Y, Gao W, Korn T, Strom TB, Oukka M, et al. Reciprocal developmental pathways for the generation of pathogenic effector TH17 and regulatory T cells. Nature (2006) 441:235-8. doi:10.1038/nature04753

243. Azevedo MDCS, Rosa PS, Soares CT, Fachin LRV, Baptista IMFD, Woods WJ, et al. Analysis of immune response markers in Jorge Lobo's disease lesions suggests the occurrence of mixed $\mathrm{T}$ helper responses with the dominance of regulatory T cell activity. PLoS One (2015) 10:e0145814. doi:10.1371/journal. pone. 0145814

244. Silva AA, Sotto MN, Duarte MI, Pagliari C. Regulatory T cells in cutaneous lesions of patients with paracoccidioidomycosis. Microb Pathog (2013) 65:36-40. doi:10.1016/j.micpath.2013.09.004

245. Felonato M, Pina A, de Araujo EF, Loures FV, Bazan SB, Feriotti C, et al. Anti-CD25 treatment depletes Treg cells and decreases disease severity in susceptible and resistant mice infected with Paracoccidioides brasiliensis. PLoS One (2012) 7:e51071. doi:10.1371/journal.pone.0051071

246. Bacher P, Kniemeyer O, Schonbrunn A, Sawitzki B, Assenmacher M, Rietschel E, et al. Antigen-specific expansion of human regulatory T cells as a major tolerance mechanism against mucosal fungi. Mucosal Immunol (2014) 7:916-28. doi:10.1038/mi.2013.107

247. Bedke T, Iannitti RG, De Luca A, Giovannini G, Fallarino F, Berges C, et al. Distinct and complementary roles for Aspergillus fumigatus-specific Tr1 and FOXP $^{+}$regulatory T cells in humans and mice. Immunol Cell Biol (2014) 92:659-70. doi:10.1038/icb.2014.34

248. Wang R, Wan Z, Li R. Th and Treg response induced by Aspergillus fumigatus pulsed dendritic cells in vitro. Chin Med J (Engl) (2014) 127:3616-22.

249. Schulze B, Piehler D, Eschke M, von Buttlar H, Kohler G, Sparwasser T, et al. $\mathrm{CD} 4^{(+)} \mathrm{FOXP}^{(+)}$regulatory $\mathrm{T}$ cells suppress fatal $\mathrm{T}$ helper 2 cell immunity during pulmonary fungal infection. Eur J Immunol (2014) 44:3596-604. doi:10.1002/eji.201444963

250. Pandiyan P, Conti HR, Zheng L, Peterson AC, Mathern DR, Hernandez-Santos $\mathrm{N}$, et al. $\mathrm{CD} 4^{(+)} \mathrm{CD}_{2} 5^{(+)} \mathrm{FOXP} 3^{(+)}$regulatory $\mathrm{T}$ cells promote $\mathrm{Th} 17$ cells in vitro and enhance host resistance in mouse Candida albicans Th17 cell infection model. Immunity (2011) 34:422-34. doi:10.1016/j.immuni.2011.03.002

251. Cereda V, Vergati M, Huen NY, di Bari MG, Jochems C, Intrivici C, et al. Maturation of human dendritic cells with Saccharomyces cerevisiae (yeast) reduces the number and function of regulatory $\mathrm{T}$ cells and enhances the ratio of antigen-specific effectors to regulatory T cells. Vaccine (2011) 29:4992-9. doi:10.1016/j.vaccine.2011.04.101 
252. Golgher D, Gazzinelli RT. Innate and acquired immunity in the pathogenesis of Chagas disease. Autoimmunity (2004) 37:399-409. doi:10.1080/08916930 410001713115

253. da Silveira AB, de Araujo FF, Freitas MA, Gomes JA, Chaves AT, de Oliveira $\mathrm{EC}$, et al. Characterization of the presence and distribution of $\mathrm{FOXP}^{(+)}$cells in chagasic patients with and without megacolon. Hum Immunol (2009) 70:65-7. doi:10.1016/j.humimm.2008.10.015

254. de Araujo FF, da Silveira AB, Correa-Oliveira R, Chaves AT, Adad SJ, Fiuza JA, et al. Characterization of the presence of FOXP3 ${ }^{(+)} \mathrm{T}$ cells from patients with different clinical forms of Chagas' disease. Hum Pathol (2011) 42:299-301. doi:10.1016/j.humpath.2010.10.002

255. de Araujo FF, Correa-Oliveira R, Rocha MO, Chaves AT, Fiuza JA, Fares RC, et al. $\mathrm{FOXP}^{+} \mathrm{CD}^{2} 5^{\text {(high) }} \mathrm{CD} 4^{+}$regulatory $\mathrm{T}$ cells from indeterminate patients with Chagas disease can suppress the effector cells and cytokines and reveal altered correlations with disease severity. Immunobiology (2012) 217:768-77. doi:10.1016/j.imbio.2012.04.008

256. Gonzalez FB, Villar SR, Fernandez Bussy R, Martin GH, Perol L, Manarin R, et al. Immunoendocrine dysbalance during uncontrolled T. cruzi infection is associated with the acquisition of a Th-1-like phenotype by FOXP3 $3^{(+)}$ T cells. Brain Behav Immun (2015) 45:219-32. doi:10.1016/j.bbi.2014. 11.016

257. Sales PA Jr, Golgher D, Oliveira RV, Vieira V, Arantes RM, Lannes-Vieira $\mathrm{J}$, et al. The regulatory $\mathrm{CD} 4^{+} \mathrm{CD} 25^{+} \mathrm{T}$ cells have a limited role on pathogenesis of infection with Trypanosoma cruzi. Microbes Infect (2008) 10:680-8. doi:10.1016/j.micinf.2008.03.008

258. Katara GK, Raj A, Kumar R, Avishek K, Kaushal H, Ansari NA, et al. Analysis of localized immune responses reveals presence of Th17 and Treg cells in cutaneous leishmaniasis due to Leishmania tropica. BMC Immunol (2013) 14:52. doi:10.1186/1471-2172-14-52

259. Cortese L, Sica M, Piantedosi D, Ruggiero G, Pero ME, Terrazzano G, et al. Secondary immune-mediated thrombocytopenia in dogs naturally infected by Leishmania infantum. Vet Rec (2009) 164:778-82. doi:10.1136/ vr.164.25.778

260. Cortese L, Annunziatella M, Palatucci AT, Rubino V, Piantedosi D, Di Loria A, et al. Regulatory $\mathrm{T}$ cells, cytotoxic $\mathrm{T}$ lymphocytes and a $\mathrm{T}(\mathrm{H}) 1$ cytokine profile in dogs naturally infected by Leishmania infantum. Res Vet Sci (2013) 95:942-9. doi:10.1016/j.rvsc.2013.08.005

261. Lee H, Kim T-S, Kang Y-J, Kim J-Y, Lee S, Lee W-J, et al. Up-regulated S100 calcium binding protein A8 in Plasmodium-infected patients correlates with $\mathrm{CD}^{+}{ }^{+} \mathrm{CD} 25^{+} \mathrm{FOXP} 3$ regulatory T cell generation. Malar J (2015) 14:385. doi:10.1186/s12936-015-0855-4

262. Bueno LL, Morais CG, Araujo FF, Gomes JA, Correa-Oliveira R, Soares IS, et al. Plasmodium vivax: induction of $\mathrm{CD} 4{ }^{+} \mathrm{CD} 25^{+} \mathrm{FOXP} 3^{+}$regulatory $\mathrm{T}$ cells during infection are directly associated with level of circulating parasites. PLoS One (2010) 5:e9623. doi:10.1371/journal.pone.0009623

263. Wu J-J, Chen G, Liu J, Wang T, Zheng W, Cao Y-M. Natural regulatory $\mathrm{T}$ cells mediate the development of cerebral malaria by modifying the pro-inflammatory response. Parasitol Int (2010) 59:232-41. doi:10.1016/j. parint.2010.02.007

264. Olguin JE, Fernandez J, Salinas N, Juarez I, Rodriguez-Sosa M, Campuzano J, et al. Adoptive transfer of $\mathrm{CD} 4^{(+)} \mathrm{FOXP}^{(+)}$regulatory T cells to C57BL/6J mice during acute infection with Toxoplasma gondii down modulates the exacerbated Th1 immune response. Microbes Infect (2015) 17:586-95. doi:10.1016/j.micinf.2015.04.002

265. Maizels RM, Balic A, Gomez-Escobar N, Nair M, Taylor MD, Allen JE. Helminth parasites-masters of regulation. Immunol Rev (2004) 201:89-116. doi:10.1111/j.0105-2896.2004.00191.x

266. Tian L, Altin JA, Makaroff LE, Franckaert D, Cook MC, Goodnow CC, et al. FOXP $3^{(+)}$regulatory T cells exert asymmetric control over murine helper responses by inducing Th2 cell apoptosis. Blood (2011) 118:1845-53. doi:10.1182/blood-2011-04-346056

267. Redpath SA, van der Werf N, Cervera AM, MacDonald AS, Gray D, Maizels $\mathrm{RM}$, et al. ICOS controls FOXP3 ${ }^{(+)}$regulatory T-cell expansion, maintenance and IL-10 production during helminth infection. Eur J Immunol (2013) 43:705-15. doi:10.1002/eji.201242794

268. Sawant DV, Gravano DM, Vogel P, Giacomin P, Artis D, Vignali DA. Regulatory $\mathrm{T}$ cells limit induction of protective immunity and promote immune pathology following intestinal helminth infection. J Immunol (2014) 192:2904-12. doi:10.4049/jimmunol.1202502
269. Turner JD, Jenkins GR, Hogg KG, Aynsley SA, Paveley RA, Cook PC, et al. $\mathrm{CD} 4{ }^{+} \mathrm{CD} 25^{+}$regulatory cells contribute to the regulation of colonic Th2 granulomatous pathology caused by schistosome infection. PLoS Negl Trop Dis (2011) 5:e1269. doi:10.1371/journal.pntd.0001269

270. Redpath SA, van der Werf N, MacDonald AS, Maizels RM, Taylor MD. Schistosoma mansoni larvae do not expand or activate $\mathrm{FOXP}^{(+)}$regulatory $\mathrm{T}$ cells during their migratory phase. Infect Immun (2015) 83:3881-9. doi:10.1128/IAI.00408-15

271. Schmiedel Y, Mombo-Ngoma G, Labuda LA, Janse JJ, de Gier B, Adegnika $\mathrm{AA}$, et al. $\mathrm{CD} 4^{+} \mathrm{CD} 25^{\mathrm{hi}} \mathrm{FOXP}^{+}$regulatory $\mathrm{T}$ cells and cytokine responses in human schistosomiasis before and after treatment with praziquantel. PLoS Negl Trop Dis (2015) 9:e0003995. doi:10.1371/journal.pntd.0003995

272. Taylor MD, Harris A, Babayan SA, Bain O, Culshaw A, Allen JE, et al. CTLA- 4 and $\mathrm{CD} 4^{+} \mathrm{CD} 25^{+}$regulatory T cells inhibit protective immunity to filarial parasites in vivo. J Immunol (2007) 179:4626-34. doi:10.4049/ jimmunol.179.7.4626

273. Taylor MD, van der Werf N, Harris A, Graham AL, Bain O, Allen JE, et al. Early recruitment of natural $\mathrm{CD}^{+}{ }^{+} \mathrm{FOXP}^{+}$Treg cells by infective larvae determines the outcome of filarial infection. Eur J Immunol (2009) 39:192-206. doi:10.1002/eji.200838727

274. Cho MK, Park MK, Kang SA, Choi SH, Ahn SC, Yu HS. Trichinella spiralis infection suppressed gut inflammation with $\mathrm{CD} 4^{(+)} \mathrm{CD} 25^{(+)} \mathrm{FOXP}^{(+)}$ $\mathrm{T}$ cell recruitment. Korean J Parasitol (2012) 50:385-90. doi:10.3347/ kjp.2012.50.4.385

275. Arce-Sillas A, Alvarez-Luquin DD, Cardenas G, Casanova-Hernandez D, Fragoso G, Hernandez M, et al. Interleukin 10 and dendritic cells are the main suppression mediators of regulatory T cells in human neurocysticercosis. Clin Exp Immunol (2016) 183:271-9. doi:10.1111/cei.12709

276. Wang Y, Zhou H, Shen Y, Wang Y, Wu W, Liu H, et al. Impairment of dendritic cell function and induction of $\mathrm{CD} 4^{(+)} \mathrm{CD} 25^{(+)} \mathrm{Foxp} 3^{(+)} \mathrm{T}$ cells by excretory-secretory products: a potential mechanism of immune evasion adopted by Echinococcus granulosus. BMC Immunol (2015) 16:44. doi:10.1186/ s12865-015-0110-3

277. Schubert LA, Jeffery E, Zhang Y, Ramsdell F, Ziegler SF. Scurfin (FOXP3) acts as a repressor of transcription and regulates $\mathrm{T}$ cell activation. J Biol Chem (2001) 276:37672-9. doi:10.1074/jbc.M104521200

278. Lyon MF, Peters J, Glenister PH, Ball S, Wright E. The scurfy mouse mutant has previously unrecognized hematological abnormalities and resembles Wiskott-Aldrich syndrome. Proc Natl Acad Sci U S A (1990) 87:2433-7. doi:10.1073/pnas.87.7.2433

279. Godfrey VL, Wilkinson JE, Russell LB. X-linked lymphoreticular disease in the scurfy (sf) mutant mouse. Am J Pathol (1991) 138:1379-87.

280. Godfrey VL, Wilkinson JE, Rinchik EM, Russell LB. Fatal lymphoreticular disease in the scurfy (sf) mouse requires $\mathrm{T}$ cells that mature in a sf thymic environment: potential model for thymic education. Proc Natl Acad Sci U S A (1991) 88:5528-32. doi:10.1073/pnas.88.13.5528

281. Clark LB, Appleby MW, Brunkow ME, Wilkinson JE, Ziegler SF, Ramsdell F. Cellular and molecular characterization of the scurfy mouse mutant. J Immunol (1999) 162:2546-54.

282. Ziegler SF. FOXP3: of mice and men. Annu Rev Immunol (2006) 24:209-26. doi:10.1146/annurev.immunol.24.021605.090547

283. Powell BR, Buist NRM, Stenzel P. An X-linked syndrome of diarrhea, polyendocrinopathy, and fatal infection in infancy. J Pediatr (1982) 100:731-7. doi:10.1016/S0022-3476(82)80573-8

284. Blair PJ, Bultman SJ, Haas JC, Rouse BT, Wilkinson JE, Godfrey VL. $\mathrm{CD} 4{ }^{+} \mathrm{CD} 8^{-} \mathrm{T}$ cells are the effector cells in disease pathogenesis in the scurfy (sf) mouse. J Immunol (1994) 153:3764-74.

285. Kanangat S, Blair P, Reddy R, Daheshia M, Godfrey V, Rouse BT, et al. Disease in the scurfy (sf) mouse is associated with overexpression of cytokine genes. Eur J Immunol (1996) 26:161-5. doi:10.1002/eji.1830260125

286. Chang X, Gao JX, Jiang Q, Wen J, Seifers N, Su L, et al. The scurfy mutation of FOXP3 in the thymus stroma leads to defective thymopoiesis. J Exp Med (2005) 202:1141-51. doi:10.1084/jem.20050157

287. Aschermann S, Lehmann CH, Mihai S, Schett G, Dudziak D, Nimmerjahn F. B cells are critical for autoimmune pathology in scurfy mice. Proc Natl Acad Sci U S A (2013) 110:19042-7. doi:10.1073/pnas.1313547110

288. Chung Y, Tanaka S, Chu F, Nurieva RI, Martinez GJ, Rawal S, et al. Follicular regulatory T cells expressing FOXP3 and Bcl-6 suppress germinal center reactions. Nat Med (2011) 17:983-8. doi:10.1038/nm.2426 
289. Linterman MA, Pierson W, Lee SK, Kallies A, Kawamoto S, Rayner TF, et al. Foxp3+ follicular regulatory $\mathrm{T}$ cells control the germinal center response. Nat Med (2011) 17(8):975-82. doi:10.1038/nm.2425

290. Smyk-Pearson SK, Bakke AC, Held PK, Wildin RS. Rescue of the autoimmune scurfy mouse by partial bone marrow transplantation or by injection with T-enriched splenocytes. Clin Exp Immunol (2003) 133:193-9. doi:10.1046/j.1365-2249.2003.02217.x

291. Levy-Lahad E, Wildin RS. Neonatal diabetes mellitus, enteropathy, thrombocytopenia, and endocrinopathy: further evidence for an X-linked lethal syndrome. J Pediatr (2001) 138:577-80. doi:10.1067/mpd.2001.111502

292. Bacchetta R, Passerini L, Gambineri E, Dai M, Allan SE, Perroni L, et al. Defective regulatory and effector $\mathrm{T}$ cell functions in patients with FOXP3 mutations. J Clin Invest (2006) 116:1713-22. doi:10.1172/JCI25112

293. Myers AK, Perroni L, Costigan C, Reardon W. Clinical and molecular findings in IPEX syndrome. Arch Dis Child (2006) 91:63-4. doi:10.1136/ adc. 2005.078287

294. McGinness JL, Bivens MM, Greer KE, Patterson JW, Saulsbury FT. Immune dysregulation, polyendocrinopathy, enteropathy, X-linked syndrome (IPEX) associated with pemphigoid nodularis: a case report and review of the literature. J Am Acad Dermatol (2006) 55:143-8. doi:10.1016/j.jaad.2005.08.047

295. Torgerson TR, Linane A, Moes N, Anover S, Mateo V, Rieux-Laucat F, et al. Severe food allergy as a variant of IPEX syndrome caused by a deletion in a noncoding region of the FOXP3 gene. Gastroenterology (2007) 132:1705-17. doi:10.1053/j.gastro.2007.02.044

296. Gambineri E, Perroni L, Passerini L, Bianchi L, Doglioni C, Meschi F, et al. Clinical and molecular profile of a new series of patients with immune dysregulation, polyendocrinopathy, enteropathy, X-linked syndrome: inconsistent correlation between forkhead box protein 3 expression and disease severity. JAllergy Clin Immunol (2008) 122: 1105-12.el. doi:10.1016/j. jaci.2008.09.027

297. Scaillon M, Van Biervliet S, Bontems P, Dorchy H, Hanssens L, Ferster A, et al. Severe gastritis in an insulin-dependent child with an IPEX syndrome. J Pediatr Gastroenterol Nutr (2009) 49:368-70. doi:10.1097/ MPG.0b013e3181a159de

298. Tsuda M, Torgerson TR, Selmi C, Gambineri E, Carneiro-Sampaio M, Mannurita SC, et al. The spectrum of autoantibodies in IPEX syndrome is broad and includes anti-mitochondrial autoantibodies. J Autoimmun (2010) 35:265-8. doi:10.1016/j.jaut.2010.06.017

299. Kobayashi I, Imamura K, Yamada M, Okano M, Yara A, Ikema S, et al. A 75-kD autoantigen recognized by sera from patients with X-linked autoimmune enteropathy associated with nephropathy. Clin Exp Immunol (1998) 111:527-31. doi:10.1046/j.1365-2249.1998.00523.x

300. Kobayashi I, Imamura K, Kubota M, Ishikawa S, Yamada M, Tonoki H, et al. Identification of an autoimmune enteropathy-related 75-kilodalton antigen. Gastroenterology (1999) 117:823-30. doi:10.1016/S0016-5085(99)70340-9

301. Kobayashi I, Kubota M, Yamada M, Tanaka H, Itoh S, Sasahara Y, et al. Autoantibodies to villin occur frequently in IPEX, a severe immune dysregulation, syndrome caused by mutation of FOXP3. Clin Immunol (2011) 141:83-9. doi:10.1016/j.clim.2011.05.010

302. Barzaghi F, Passerini L, Bacchetta R. Immune dysregulation, polyendocrinopathy, enteropathy, $\mathrm{x}$-linked syndrome: a paradigm of immunodeficiency with autoimmunity. Front Immunol (2012) 3:211. doi:10.3389/fimmu.2012.00211

303. Bennett CL, Christie J, Ramsdell F, Brunkow ME, Ferguson PJ, Whitesell L, et al. The immune dysregulation, polyendocrinopathy, enteropathy, X-linked syndrome (IPEX) is caused by mutations of FOXP3. Nat Genet (2001) 27(1):20-1. doi:10.1038/83713

304. Bennett CL, Brunkow ME, Ramsdell F, O’Briant KC, Zhu Q, Fuleihan RL, et al. A rare polyadenylation signal mutation of the FOXP3 gene (AAUAAA $>$ AAUGAA) leads to the IPEX syndrome. Immunogenetics (2001) 53:435-9. doi:10.1007/s002510100358

305. Wildin RS, Smyk-Pearson S, Filipovich AH. Clinical and molecular features of the immunodysregulation, polyendocrinopathy, enteropathy, X linked (IPEX) syndrome. J Med Genet (2002) 39:537-45. doi:10.1136/jmg.39.8.537

306. Chen CA, Chung WC, Chiou YY, Yang YJ, Lin YC, Ochs HD, et al. Quantitative analysis of tissue inflammation and responses to treatment in immune dysregulation, polyendocrinopathy, enteropathy, X-linked syndrome, and review of literature. J Microbiol Immunol Infect (2015) 49(5):775-82. doi:10.1016/j.jmii.2015.10.015
307. Kucuk ZY, Bleesing JJ, Marsh R, Zhang K, Davies S, Filipovich AH. A challenging undertaking: stem cell transplantation for immune dysregulation, polyendocrinopathy, enteropathy, X-linked (IPEX) syndrome. J Allergy Clin Immunol (2016) 137: 953-5.e4. doi:10.1016/j.jaci.2015.09.030

308. Hoogendoorn B, Coleman SL, Guy CA, Smith K, Bowen T, Buckland PR, et al. Functional analysis of human promoter polymorphisms. Hum Mol Genet (2003) 12:2249-54. doi:10.1093/hmg/ddg246

309. Bassuny WM, Ihara K, Sasaki Y, Kuromaru R, Kohno H, Matsuura N, et al. A functional polymorphism in the promoter/enhancer region of the FOXP3/Scurfin gene associated with type 1 diabetes. Immunogenetics (2003) 55:149-56. doi:10.1007/s00251-003-0559-8

310. Oda JM, Hirata BK, Guembarovski RL, Watanabe MA. Genetic polymorphism in FOXP3 gene: imbalance in regulatory T-cell role and development of human diseases. J Genet (2013) 92:163-71. doi:10.1007/s12041-013-0213-7

311. Wu Z, You Z, Zhang C, Li Z, Su X, Zhang X, et al. Association between functional polymorphisms of FOXP3 Gene and the occurrence of unexplained recurrent spontaneous abortion in a Chinese Han population. Clin Dev Immunol (2012) 2012:7. doi:10.1155/2012/896458

312. Song QH, Shen Z, Xing XJ, Yin R, Wu YZ, You Y, et al. An association study of single nucleotide polymorphisms of the FOXP3 intron- 1 and the risk of Psoriasis vulgaris. Indian J Biochem Biophys (2012) 49:25-35.

313. Zhang Y, Duan S, Wei X, Zhao Y, Zhao L, Zhang L. Association between polymorphisms in FOXP3 and EBI3 genes and the risk for development of allergic rhinitis in Chinese subjects. Hum Immunol (2012) 73:939-45. doi:10.1016/j.humimm.2012.07.319

314. Park O, Grishina I, Leung PS, Gershwin ME, Prindiville T. Analysis of the FOXP3/scurfin gene in Crohn's disease. Ann N Y Acad Sci (2005) 1051:21828. doi:10.1196/annals.1361.125

315. Saxena D, Misra MK, Parveen F, Phadke SR, Agrawal S. The transcription factor Forkhead Box P3 gene variants affect idiopathic recurrent pregnancy loss. Placenta (2015) 36:226-31. doi:10.1016/j.placenta.2014.11.014

316. Song P, Wang XW, Li HX, Li K, Liu L, Wei C, et al. Association between FOXP3 polymorphisms and vitiligo in a Han Chinese population. $\mathrm{Br}$ J Dermatol (2013) 169:571-8. doi:10.1111/bjd.12377

317. Inoue $\mathrm{N}$, Watanabe $\mathrm{M}$, Morita $\mathrm{M}$, Tomizawa $\mathrm{R}$, Akamizu $\mathrm{T}$, Tatsumi K, et al. Association of functional polymorphisms related to the transcriptional level of FOXP3 with prognosis of autoimmune thyroid diseases. Clin Exp Immunol (2010) 162:402-6. doi:10.1111/j.1365-2249.2010.04229.x

318. Barbosa CP, Teles JS, Lerner TG, Peluso C, Mafra FA, Vilarino FL, et al. Genetic association study of polymorphisms FOXP3 and FCRL3 in women with endometriosis. Fertil Steril (2012) 97:1124-8. doi:10.1016/j. fertnstert.2012.01.125

319. Andre GM, Barbosa CP, Teles JS, Vilarino FL, Christofolini DM, Bianco B. Analysis of FOXP3 polymorphisms in infertile women with and without endometriosis. Fertil Steril (2011) 95:2223-7. doi:10.1016/j.fertnstert.2011. 03.033

320. Bossowski A, Borysewicz-Sanczyk H, Wawrusiewicz-Kurylonek N, Zasim A, Szalecki M, Wikiera B, et al. Analysis of chosen polymorphisms in FoxP3 gene in children and adolescents with autoimmune thyroid diseases. Autoimmunity (2014) 47:395-400. doi:10.3109/08916934.2014.910767

321. Bottema RW, Kerkhof M, Reijmerink NE, Koppelman GH, Thijs C, Stelma FF, et al. X-chromosome Forkhead Box P3 polymorphisms associate with atopy in girls in three Dutch birth cohorts. Allergy (2010) 65:865-74. doi:10.1111/j.1398-9995.2009.02291.x

322. Lan Y, Tang XS, Qin J, Wu J, Qin JM. [Association of transcription factor FOXP3 gene polymorphism with genetic susceptibility to systematic lupus erythematosus in Guangxi Zhuang population]. Zhonghua Yi Xue Yi Chuan Xue Za Zhi (2010) 27:433-6. doi:10.3760/cma.j.issn.1003-9406.2010. 04.016

323. Eastell T; BSPAR Study Group, Hinks A, Thomson W. SNPs in the FOXP3 gene region show no association with Juvenile Idiopathic Arthritis in a UK Caucasian population. Rheumatology (Oxford) (2007) 46:1263-5. doi:10.1093/rheumatology/kem129

324. Shen Z, Chen L, Hao F, Wang G, Liu Y.Intron-1 rs3761548 is related to the defective transcription of FOXP3 in psoriasis through abrogating E47/c-Myb binding. J Cell Mol Med (2010) 14:226-41. doi:10.1111/j.1582-4934.2008.00370.x

325. Fodor E, Garaczi E, Polyanka H, Koreck A, Kemeny L, Szell M. The rs 3761548 polymorphism of FOXP3 is a protective genetic factor against allergic 
rhinitis in the Hungarian female population. Hum Immunol (2011) 72:926-9. doi:10.1016/j.humimm.2011.06.011

326. Jahan P, Cheruvu R, Tippisetty S, Komaravalli PL, Valluri V, Ishaq M. Association of FOXP3 (rs3761548) promoter polymorphism with nondermatomal vitiligo: a study from India. J Am Acad Dermatol (2013) 69:262-6. doi:10.1016/j.jaad.2013.01.035

327. Gao L, Li K, Li F, Li H, Liu L, Wang L, et al. Polymorphisms in the FOXP3 gene in Han Chinese psoriasis patients. JDermatol Sci (2010) 57:51-6. doi:10.1016/j.jdermsci.2009.09.010

328. He Y, Na H, Li Y, Qiu Z, Li W. FOXP3 rs3761548 polymorphism predicts autoimmune disease susceptibility: a meta-analysis. Hum Immunol (2013) 74:1665-71. doi:10.1016/j.humimm.2013.08.270

329. He YQ, Bo Q, Yong W, Qiu ZX, Li YL, Li WM. FOXP3 genetic variants and risk of non-small cell lung cancer in the Chinese Han population. Gene (2013) 531:422-5. doi:10.1016/j.gene.2013.08.066

330. Jahan P, Ramachander VR, Maruthi G, Nalini S, Latha KP, Murthy TS. FOXP3 promoter polymorphism (rs3761548) in breast cancer progression: a study from India. Tumour Biol (2014) 35:3785-91. doi:10.1007/s13277-013-1501-9

331. D’Amico F, Skarmoutsou E, Marchini M, Malaponte G, Caronni M, Scorza $\mathrm{R}$, et al. Genetic polymorphisms of FOXP3 in Italian patients with systemic sclerosis. Immunol Lett (2013) 152:109-13. doi:10.1016/j.imlet.2013.05.006

332. Ban Y, Tozaki T, Tobe T, Ban Y, Jacobson EM, Concepcion ES, et al. The regulatory T cell gene FOXP3 and genetic susceptibility to thyroid autoimmunity: an association analysis in Caucasian and Japanese cohorts. J Autoimmun (2007) 28:201-7. doi:10.1016/j.jaut.2007.02.016

333. Engela AU, Boer K, Roodnat JI, Peeters AM, Eilers PH, Kal-van Gestel JA, et al. Genetic variants of FOXP3 influence graft survival in kidney transplant patients. Hum Immunol (2013) 74:751-7. doi:10.1016/j.humimm.2013.02.008

334. Sánchez E, Rueda B, Orozco G, Oliver J, Vilchez JR, Paco L, et al. Analysis of a GT microsatellite in the promoter of the FOXP3/scurfin gene in autoimmune diseases. Hum Immunol (2005) 66:869-73. doi:10.1016/j. humimm.2005.06.001
335. Oertelt S, Kenny TP, Selmi C, Invernizzi P, Podda M, Gershwin ME. SNP analysis of genes implicated in $\mathrm{T}$ cell proliferation in primary biliary cirrhosis. Clin Dev Immunol (2005) 12(4):259-63.

336. Chen Y, Zhang H, Liao W, Zhou J, He G, Xie X, et al. FOXP3 gene polymorphism is associated with hepatitis B-related hepatocellular carcinoma in China. J Exp Clin Cancer Res (2013) 32:39. doi:10.1186/1756-9966-32-39

337. Zhang J, Chen Y, Jia G, Chen X, Lu J, Yang H, et al. FOXP3 -3279 and IVS9+459 polymorphisms are associated with genetic susceptibility to myasthenia gravis. Neurosci Lett (2013) 534:274-8. doi:10.1016/j.neulet.2012.11.048

338. Haghighi MF, Ghayumi MA, Behzadnia F, Erfani N. Investigation of FOXP3 genetic variations at positions-2383 C/T and IVS9+ $459 \mathrm{~T} / \mathrm{C}$ in southern Iranian patients with lung carcinoma. Iran J Basic Med Sci (2015) 18:465.

339. Kim KH, Kim TM, Go H, Kim WY, Jeon YK, Lee SH, et al. Clinical significance of tumor-infiltrating $\mathrm{FOXP}^{+} \mathrm{T}$ cells in patients with ocular adnexal mucosa-associated lymphoid tissue lymphoma. Cancer Sci (2011) 102:1972-6. doi:10.1111/j.1349-7006.2011.02051.x

340. Bafunno V, Santacroce R, Chetta M, D’Andrea G, Pisanelli D, Sessa F, et al. Polymorphisms in genes involved in autoimmune disease and the risk of FVIII inhibitor development in Italian patients with haemophilia A. Haemophilia (2010) 16:469-73. doi:10.1111/j.1365-2516.2009.02150.x

Conflict of Interest Statement: The authors declare that the research was conducted in the absence of any commercial or financial relationships that could be construed as a potential conflict of interest.

Copyright $\odot 2017$ Pereira, Gomes, Ishak and Vallinoto. This is an open-access article distributed under the terms of the Creative Commons Attribution License (CC BY). The use, distribution or reproduction in other forums is permitted, provided the original author(s) or licensor are credited and that the original publication in this journal is cited, in accordance with accepted academic practice. No use, distribution or reproduction is permitted which does not comply with these terms. 